\title{
Piecing together a new mosaic: Gravettian lithic resources and economic territories in the Western Pyrenees
}

\author{
Aitor Calvo $^{1,2}$ (D) Alvaro Arrizabalaga ${ }^{2}$ (D) \\ Received: 20 July 2020 / Accepted: 22 October 2020/Published online: 26 November 2020 \\ (C) The Author(s) 2020
}

\begin{abstract}
To palliate the current scarcity of information about lithic raw materials in the Western Pyrenees during the Gravettian, the study of ten assemblages has explored the flint procurement patterns and economic organisation of the territory. The study was based on the macro- and microscopic analysis of the different lithic remains. A wide range of flint varieties were used, including some excellent rocks for knapping and others of poorer quality. This diversified catchment pattern was defined by the criteria of quality and suitability for reduction. Although procurement took place mostly at the primary outcrops, there is some evidence of limited acquisition in secondary deposits. Within the economic territory of the Western Pyrenees, divergences in the connections between the outcrops on one side of the mountains and the archaeological sites on the other may indicate different territorial or economic roles for each side. In general terms, the northern side may have been more residential with more stable habitation, while the southern side was linked with logistic tasks and more seasonal occupation. The economic connections between this territory and surrounding areas revealed by the lithic resources are the reflection of inter-group contacts and an economic mosaic imbricated with a cultural or symbolic one.
\end{abstract}

Keywords Raw materials $\cdot$ Lithic industry $\cdot$ Territory $\cdot$ Economy $\cdot$ Upper Palaeolithic $\cdot$ Gravettian

\section{Introduction}

The study of raw materials is currently the best window affording a glimpse of Palaeolithic economy and geography. The gradual progress in the characterisation of lithic resources during the last four decades has enabled studies that until then could not have been addressed, such as procurement patterns (e.g. Tarriño 2000; Aubry et al. 2004; Sauer 2016; Sánchez et al. 2016; Gómez de Soler et al. 2020) or the mobility and territoriality of Palaeolithic populations (e.g. Blades 1999; Fernandes et al. 2008; Aubry et al. 2012; Fontes et al. 2016; Turq et al. 2017), among others. Furthermore, the relation

Aitor Calvo

aitor.calvo@ehu.eus

1 Institute of Prehistory and Protohistory, Department of Classical World and Asian Cultures, Friedrich-Alexander University of Erlangen-Nuremberg (FAU), Kochstr. 4/18, 91054 Erlangen, Germany

2 Department of Geography, Prehistory and Archaeology, University of the Basque Country (UPV/EHU), Paseo de la Universidad 5, 01006 Vitoria-Gasteiz, Spain between raw material data and typological, technological, typometric and use-wear information is allowing the determination of their management and use patterns (e.g. RiosGaraizar 2012; Arrizabalaga et al. 2014; García-Rojas 2014; Calvo 2019; Calvo et al. 2019; Prieto et al. 2020).

In the Western Pyrenees, research on lithic raw materials has concentrated on flint, the main resource in the whole of the Upper Palaeolithic in this region. The first geological studies of the outcrops potentially used in prehistory began in the 1980s. To the north of the mountain range, they focused on outcrops in the Chalosse area (Normand 1986), whereas to the south they mainly examined the outcrops in the coastal Flysch formations (Elorza and Bustillo 1989) and on the Mediterranean side of the watershed in the Basque Country (Tarriño et al. 1989). This research continued during the following decade and was complemented by the first petrographic, palaeontological and geochemical characterisation of siliceous rocks, in some cases as part of the studies determining the provenance of flint types in Palaeolithic sites (SéronieVivien 1994; Bon et al. 1996; Tarriño and Aguirre 1997; Tarriño et al. 1998; Normand 2002; Tarriño 2006). At the start of the present century, provenance studies became more widespread and systematic, as the necessary knowledge 
foundations were enlarged and consolidated. Finally, in the last decade, new methods and approaches have been added to the study of lithic raw materials (e.g. Fernandes 2012; Prieto et al. 2016; Sánchez de la Torre et al. 2019). However, in the case of the Gravettian technocomplex the analysis of lithic resources has been scarce and sometimes preliminary and very partial (Simonet 2010; 2012a; Tarriño and Elorrieta 2012).

Therefore, in this first large-scale study about the procurement of lithic raw materials during the Gravettian in the Western Pyrenees (Calvo 2019), the results of the analysis and identification of flint from ten levels or assemblages at six archaeological sites will be described and discussed. As will be explained in detail, these assemblages cover a long chronology from the late Aurignacian to the early Solutrean, thus representing the time of the emergence, development and disappearance of the Gravettian in the region of study.

Two objectives were set. The first was to reconstruct the flint procurement patterns. In this sense, the lack of information alluded to above has been palliated through the study of levels that had not been considered in this aspect before, at the sites of Amalda, Usategi and Gatzarria, and important sites for which only preliminary data was available, like Bolinkoba (Tarriño and Aguirre 1997). These have been complemented by the assemblages from Ametzagaina, researched by the present authors a few years ago (Arrizabalaga et al. 2014), and Aitzbitarte III, studied by Tarriño (2011), which have been restudied here by increasing the sample from each level considerably.

The second objective was to explore the economic organisation of the territory by the communities that inhabited in the Western Pyrenees during that long period. Although territoriality has been approached in this geographic and chronological framework through other archaeological evidence, it has rarely been based on the lithic resources (Barandiarán 1980; Foucher 2004; Foucher and San Juan-Foucher 2008; Arrizabalaga et al. 2014; Simonet 2017).

\section{Materials and methods}

\section{The lithic assemblages: chronological and material context}

As stated above, ten levels or lithic assemblages from six archaeological sites were studied (Table 1 and Fig. 1). These sites cover a significant part of the area of study and the whole cycle of the Gravettian technocomplex in the Western Pyrenees (34-32 to 26-24 ky cal BP). They include both an open-air site (Ametzagaina) and cave deposits, and sites with different degrees of occupation and probably of diverse functions (Simonet 2017). However, specifying the nature of these sites is not easy. Considering the vast lithic assemblage recovered (which includes more than 1500 Noailles burins), which appears certain is that Aitzbitarte III cave was an important dwelling place, repeatedly occupied during the Gravettian (San Emeterio and Ríos-Garaizar 2017). The important lithic and osseous assemblage from Bolinkoba also indicates that this cave was a relevant and recurrent settlement, although its small size indicates that the groups that inhabited it would have necessarily been reduced. For the same reasons, Amalda cave was also a significant settlement, although its functionality is not clear. The Ametzagaina open-air site has been interpreted as a camp-site with no specific functionality, owing its location and the composition of the lithic assemblage (Calvo et al. 2013; Arrizabalaga et al. 2014). However, the proximity of the outcrops of Gaintxurizketa Flysch could have been an important factor in its occupation. Which appears also certain is that Usategi cave holds a very occasional occupation, playing the role as a transit point (Calvo and Arrizabalaga, in prep.). Finally, the occupation of Gatzarria cave was also modest and of uncertain functionality.

From the material point of view, four of the assemblages contain a significant proportion of Noailles burins (Bolinkoba VI/F, Amalda VI, Ametzagaina Eastern Assemblage and Gatzarria Cbcs), which clearly links them with the Gravettian. Additionally, level VI/F at Bolinkoba yielded a fragment of an Isturitz-type bone point, which supports that attribution. Both this latter level and level VI at Amalda were dated by radiocarbon to the Gravettian technocomplex (Altuna 1992; IriarteChiapusso and Arrizabalaga 2015; Marín-Arroyo et al. 2018). For level VI/F at Bolinkoba, the dates range between ca. 26 and $21 \mathrm{ky} \mathrm{BP}(30-25 \mathrm{ky}$ cal BP), whereas for Amalda level VI they vary between ca. 29 and $26 \mathrm{ky} \mathrm{BP} \mathrm{(34-30} \mathrm{ky} \mathrm{cal} \mathrm{BP).} \mathrm{In} \mathrm{the}$ case of Usategi, the presence of another fragment of an Isturitztype bone point equally associates this site with the Gravettian, and this has been supported by recent radiocarbon dates (Calvo and Arrizabalaga, in prep.).

The attribution of the other levels is more uncertain. The one that most clearly belongs to the Gravettian is level IV in the entrance sector at Aitzbitarte III. The available dates cover a long period of time (Altuna 2011; Marín-Arroyo et al. 2018), as they range between ca. 29 and $22 \mathrm{ky} \mathrm{BP} \mathrm{(34-26} \mathrm{ky} \mathrm{cal} \mathrm{BP).}$ Apart from a few Noailles burins, this level contains no other diagnostic remains, but the composition of the lithic assemblage would not be out of place in other Gravettian collections and it does not include any element diagnostic of a different technocomplex. The two lower levels, upper $\mathrm{Vb}$ and $\mathrm{Va}$, are linked to the evolved Aurignacian or very early Gravettian by radiocarbon dates (Altuna 2011; Marín-Arroyo et al. 2018). The two dates for upper $\mathrm{Vb}$ situate it between ca. 32.5 and 31 ky BP (37-35 ky cal BP), while those for level Va range between ca. 31.5 and 26 ky BP (36-29.5 ky cal BP). Again, the assemblages from both levels do not contain diagnostic artefacts apart from a few Noailles burins. However, their techno-typological traits are compatible with the Gravettian. Practically all the dates for level III in the entrance sector of 
Table 1 General information about the sites, levels and assemblages studied

\begin{tabular}{|c|c|c|c|c|c|}
\hline Site & Level/assemblage & $\begin{array}{l}\text { Chrono-cultural } \\
\text { attribution }\end{array}$ & $\begin{array}{l}\text { Total } \\
\text { remains }\end{array}$ & Retouched & $\begin{array}{l}\text { Non- } \\
\text { retouched }\end{array}$ \\
\hline Bolinkoba & $\mathrm{VI} / \mathrm{F}$ & Gravettian & 2506 & 591 & 1915 \\
\hline \multirow[t]{2}{*}{ Amalda } & VI & Gravettian & 2264 & 383 & 1881 \\
\hline & $\mathrm{V}$ & Grav.-Early Solutrean & 829 & 130 & 699 \\
\hline Usategi & III and IV & Gravettian & 29 & 7 & 22 \\
\hline Ametzagaina & $\begin{array}{l}\text { Eastern } \\
\quad \text { assemblage }\end{array}$ & Gravettian & 2436 & 356 & 2080 \\
\hline \multirow{4}{*}{$\begin{array}{l}\text { Aitzbitarte } \\
\text { III }\end{array}$} & Upper $\mathrm{Vb}$ & Evol. Aur.-Gravettian & 649 & 87 & 562 \\
\hline & $\mathrm{Va}$ & Evol. Aur.-Gravettian & 921 & 105 & 816 \\
\hline & IV & Gravettian & 1045 & 102 & 943 \\
\hline & III & Grav.-Early Solutrean & 1534 & 164 & 1370 \\
\hline \multirow[t]{2}{*}{ Gatzarria } & Cbcs & Gravettian & 520 & 113 & 407 \\
\hline & & & 12,733 & 2038 & 10,695 \\
\hline
\end{tabular}

the cave (Altuna 2011) overstep the widely accepted limit for the technocomplex, as they range from ca. 23 to $18 \mathrm{ky} \mathrm{BP}$ (27.5-21.5 ky cal BP). Thus, this level is on the boundary between the late Gravettian and early Solutrean (Calvo and Prieto 2012). While leaf-shaped artefacts are absent, the presence of a bone needle might link it with the more recent technocomplex. In contrast, a small sample of Noailles burins would relate it to the Gravettian, although it should be noted that these appear to continue in some Solutrean sites on the south side of the Western Pyrenees (Arrizabalaga 1994). Finally, level V at Amalda suffers from a similar problem: the two radiocarbon dates (Altuna 1992) relate it to the Solutrean, between ca. 19.5 and 17.5 ky BP (24-20.5 ky cal BP). However, the assemblage contains no elements diagnostic of either the Gravettian or Solutrean and it is compatible with either of them.

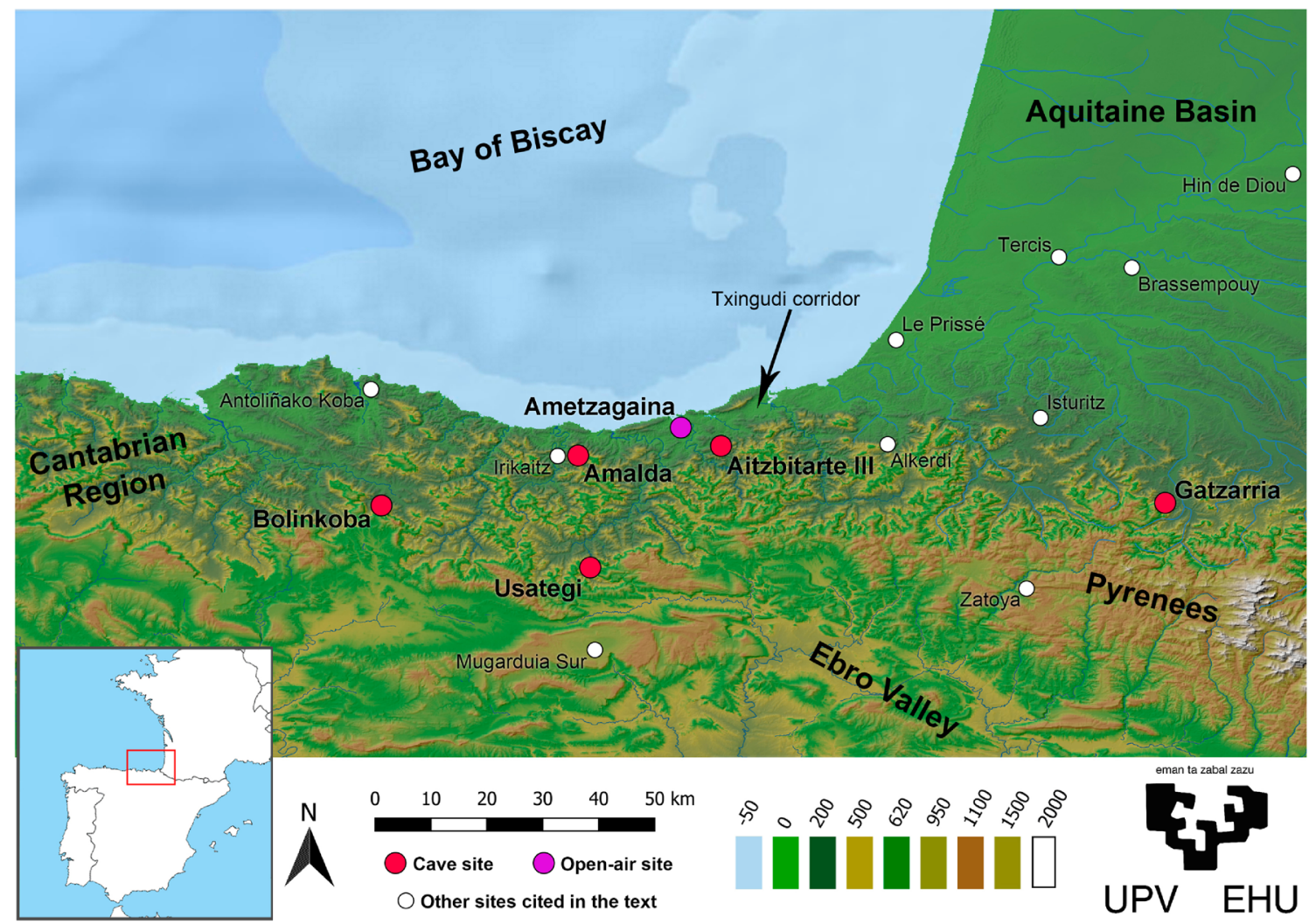

Fig. 1 Map with the location of the sites studied here and other Western Pyrenean sites mentioned in the text 
Table 2 Main flint types and their varieties, according to their age and group, defined by their formation environment (references in the text)

\begin{tabular}{llll}
\hline Group (formation environment) & Age & Type & Variety \\
\hline Deep Marine Basin (Pelagic) & Upper Cretaceous & Salies-de-Béarn & - \\
& & Tercis & Type 1 \\
& & & Type 2 \\
Marine Basin Slope (Flysch) & Palaeocene & Artxilondo & Type 3 \\
& Upper Cretaceous & Kurtzia & - \\
& & Bidache & - \\
& & Iholdy & - \\
External Marine Platform & & Gaintxurizketa & - \\
& Palaeocene & Urbasa & - \\
Internal Marine Platform & Upper Cretaceous & Chalosse & Audignon \\
Reef Platform & & & Bastennes-Gaujacq \\
Continental (Lacustrine-Palustrine) & Palaeocene & Loza & - \\
& Lower Cretaceous & Urgonian & - \\
& & Treviño & Nodular micritic \\
& & & Clotted silcrete \\
& & & Brecciated silcrete \\
& & & Algae banded \\
\hline
\end{tabular}

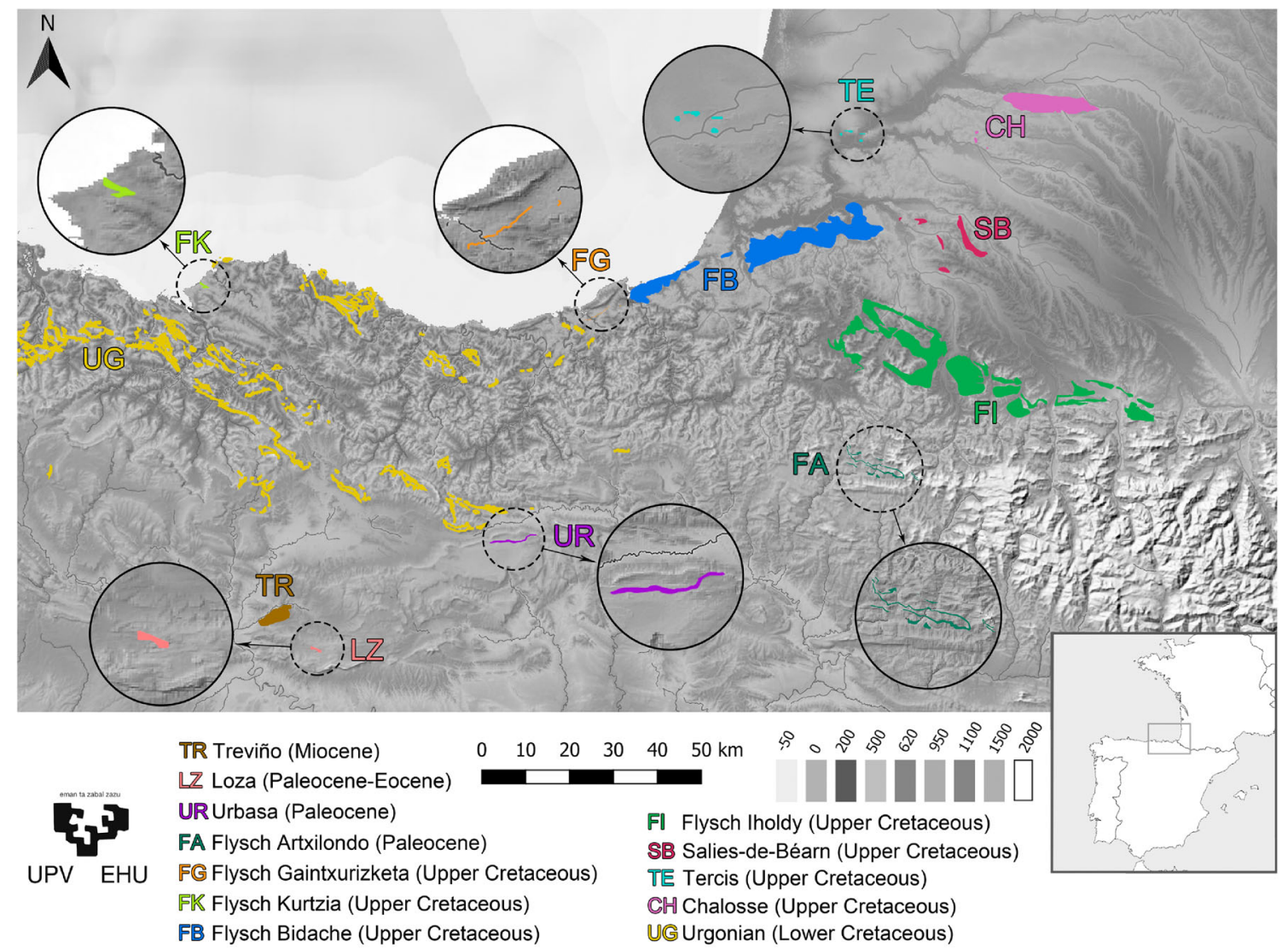

Fig. 2 Map with the location of the main flint outcrops in the Western Pyrenees exploited in the Palaeolithic (see below for details) 


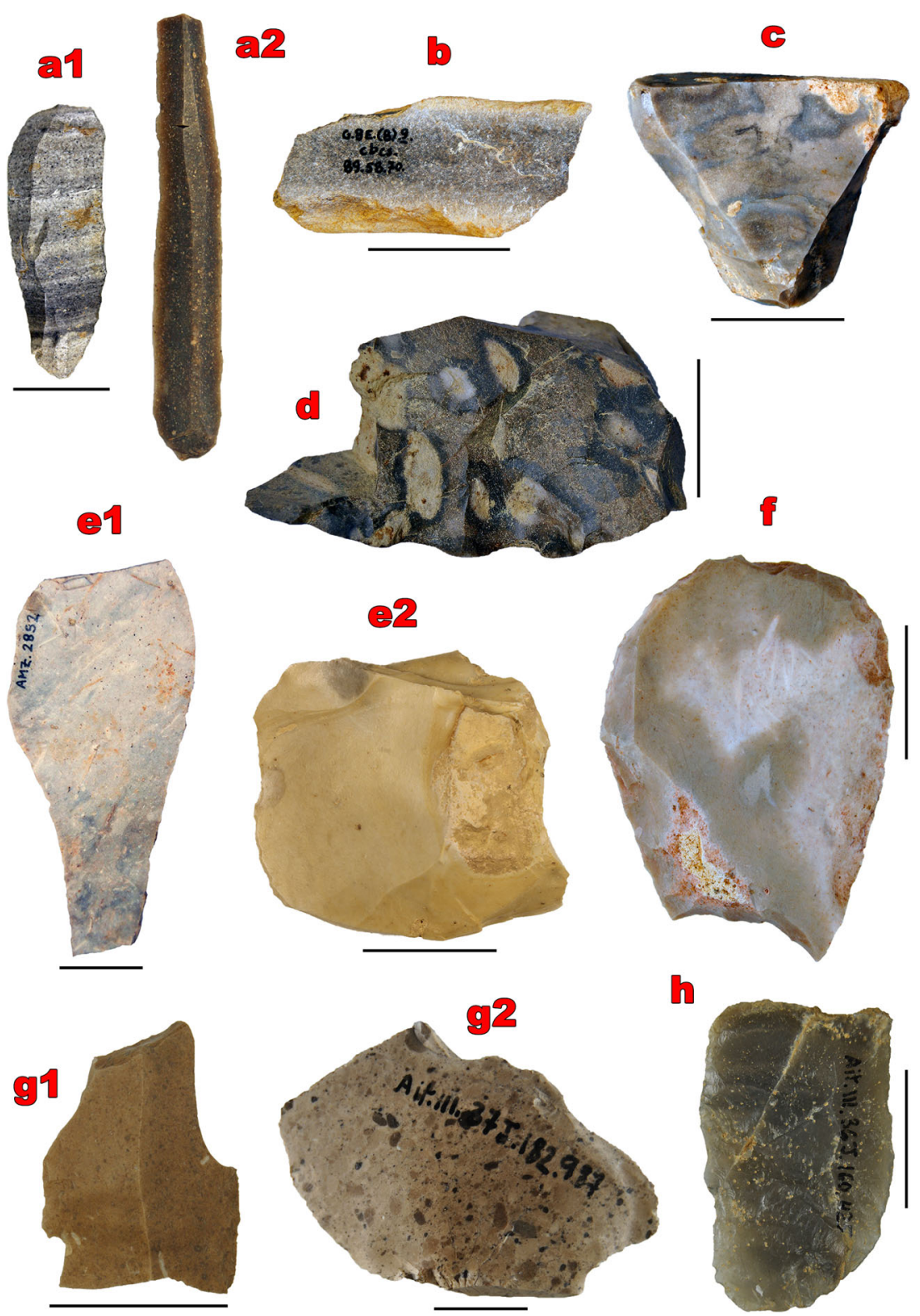

Fig. 3 Photographs of representative remains of the main flint types and varieties identified in the present research. a1 Patinated blade of Bidache Flysch flint, displaying turbiditic lamination and bioclastic spotted appearance (from Aitzbitarte III); a2 'fresh' flint blade in Bidache Flysch flint, with its usually brownish colour (from Ametzagaina); b fragment of an Iholdy Flysch nodule, with its characteristic dark colour (from Gatzarria); c core in Salies-de-Béarn flint; observe its zoned appearance and the presence of bioturbations in the upper right part (from Gatzarria); d denticulate in Gaintxurizketa Flysch flint, in which transversal sections of bioturbations rich in relict carbonates can be observed (from Ametzagaina): e11 patinated backed tool in Chalosse flint, probably the Audignon variety, with its characteristic bioclastic wackestone

\section{Siliceous raw materials in the Western Pyrenees}

The Western Pyrenees is an area that is rich in lithic resources, especially flint. Of the multiple geological strata and deposits containing this raw material, at least 12 were exploited more texture (from Ametzagaina); $\mathbf{2} 2$ patinated core in Chalosse flint, probably the Bastennes-Gaujacq variety, with its usual homogeneous mudstone texture with few bioclastic remains (from Aitzbitarte III); f endscraper in partially patinated Urbasa flint; several foraminifera, which cause the characteristic bioclastic appearance in the patinated part, can be observed on the right (from Aitzbitarte III); g1 patinated burin in Treviño flint, a bioclastic nodular variety (micrite) with its typical brownish colour (from Amalda); $\mathbf{g} 2$ patinated flake in Treviño flint, a brecciated silcrete variety with its characteristic spotted texture (from Aitzbitarte III); h)sidescraper in Urgonian flint, in which its porosity and the habitual fractures in the nodules of this resource can be appreciated (from Aitzbitarte III). All the scales are of $1 \mathrm{~cm}$

or less systematically during Palaeolithic (Normand 2002; Tarriño 2006; Fernandes 2012; Tarriño et al. 2015) (Fig. 2). The respective types are divided into six groups, defined by their formation environment. They range from the Cretaceous to the Neogene in age (Table 2). 

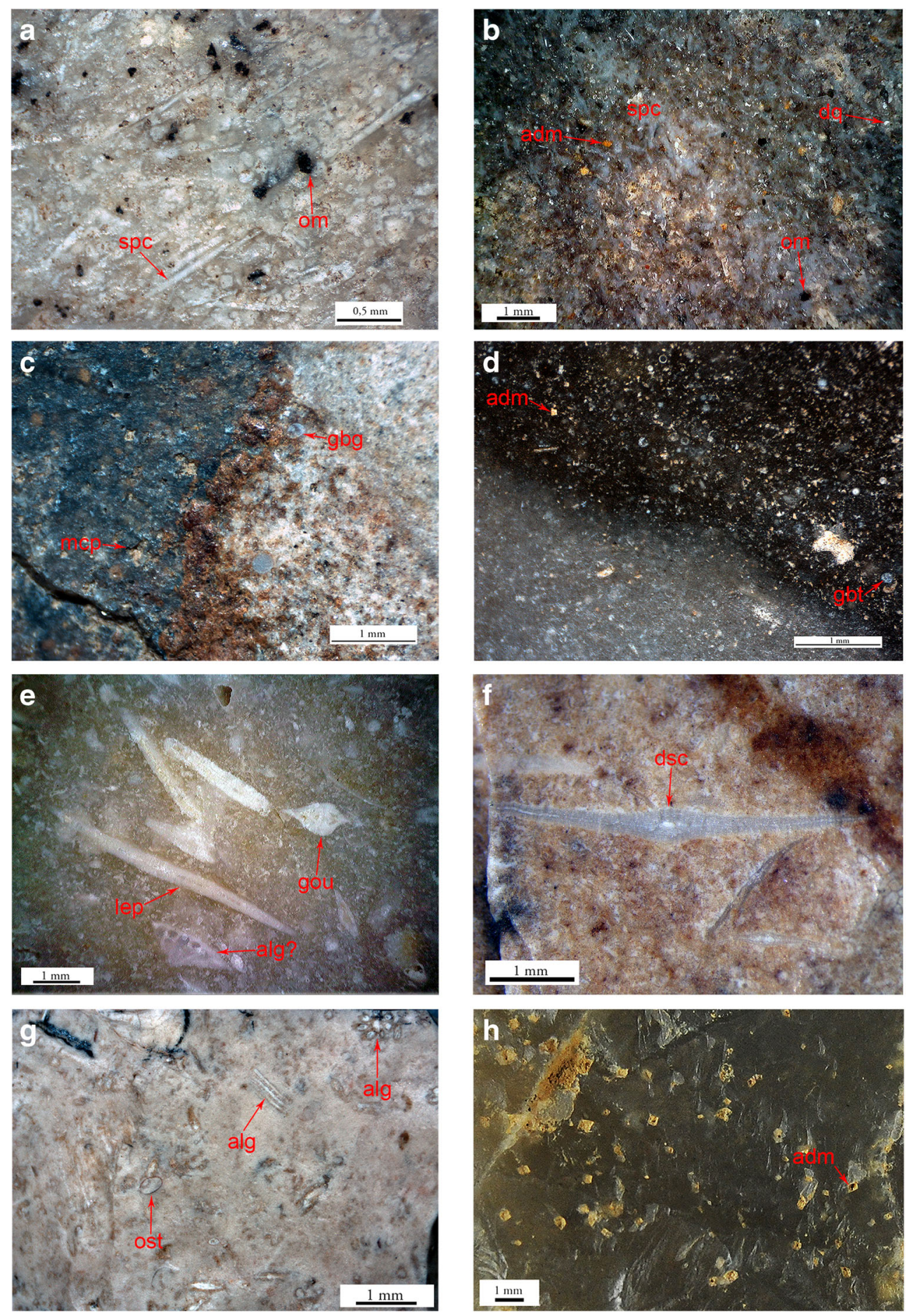

Urgonian flint, Aptian-Albian in age, belongs to the Lower Cretaceous. It is widely distributed geographically, as silicifications are found throughout the Urgonian Complex in the whole of Basque-Cantabrian Basin. Tarriño (2006) estimates that as many as 20 outcrops may have been exploited during prehistory. It may have originated in two ways: as diagenetic silicifications or as hydrothermal silicifications associated with mineralisations (Aranburu 1998). The nodules usually display numerous fissures and mouldic microporosity caused by the dissolution of authigenic dolomite crystals (Figs. $3 \mathrm{~h}$ and $4 \mathrm{~h})$.

Most of the Flysch types correspond to the Upper Cretaceous, between the Cenomanian and the Campanian. They outcrop on both sides of the Western Pyrenees: in the Kurtzia (Barrika, Biscay) and Gaintxurizketa (Lezo-Irun, Gipuzkoa) outcrops to the south, and the Bidache (BidartBayonne-Mouguerre, Pyrénées-Atlantiques) and Iholdy (Iholdy, Pyrénées-Atlantiques) ones to the north (Normand 
4 Fig. 4 Microscopic photographs of the texture of the main types and varieties of flint identified during this research. a Patinated piece of Flysch flint (Kurtzia or Bidache) showing the characteristic bioclastic texture of this type; the bioclasts include sponge spicules (spc) and the spots of organic matter (om) are also common (from Amalda). b Piece of Iholdy Flysch flint with its typical bioclastic texture, including sponge spicules $(\mathrm{spc})$, spots of organic matter (om), grains of detritic quartz (dq) and rhombohedral crystals of ferruginised authigenic dolomite (adm) (from Gatzarria). c Piece of Gaintxurizketa Flysch flint with the separation zone between a bioturbation rich in carbonate relicts (whitish, on the right) and the rest of the matrix (dark blue, on the left); several micropores (mcp) can be seen in the latter, caused by the dissolution of authigenic dolomite crystals, and two sections of Globigerinidae (gbg) are visible in the bioturbation (from Ametzagaina). d Salies-de-Béarn flint with its characteristic zonation, bioclastic texture with several possible Globotruncanidae (gbt) and the presence of idiomorphic crystals of ferruginised or dissolved authigenic dolomite (adm) (from Amalda). e Chalosse flint (possibly the Audignon variety) with its usual wackestone texture and benthic foraminifera of the Lepidorbitoides (lep) and Goupillaudina (gou) genera, as well as possible algae (alg?) (from Aitzbitarte IIII). f patinated piece of Urbasa flint with its typical bioclastic texture in which two sections of Discocyclinidae (dsc) are visible (from Ametzagaina). g Patinated piece of Treviño flint (nodular or micritic bioclastic variety) showing its bioclastic texture with Characeae algae (alg) and ostracods (ost) (from Amalda). h Urgonian flint, in which idiomorphic crystals of ferruginised or dissolved authigenic dolomite (adm) are visible (from Aitzbitarte III)

2002; Tarriño 2006; Fernandes 2012). They are bioclastic flints with a grainstone texture containing sponge spicules, detritic quartz and heavy minerals (iron sulphides), as well as mouldic microporosity caused by the alteration (ferruginisation and dissolution) of authigenic dolomite crystals (especially noticeable in the Gaintxurizketa type). They sometimes display parallel or undulating turbiditic laminations (Figs. 3a1, a2, b and 4a, b). Gaintxurizketa also contains planktonic Globigerina foraminifera and bioturbations rich in relict carbonates, which give it a zoned appearance (Arrizabalaga et al. 2014) (Figs. 3d and 4c).

The main silicifications of the Chalosse type date from the Campanian and Maastrichtian. They outcrop in two distinct areas, the Audignon-Montaut anticline and the BastennesGaujacq diapir (Landes), between the towns of Orthez, Dax and Mont-de-Marsan. They are fine-grained types with a texture between mudstone and wackestone. Algae (Codiaceae), bryozoans and benthic (Lepidorbitoides, Orbitoides and Siderolites, among others) and planktonic (less abundant) foraminifera appear in the bioclastic specimens. They usually display zonations in a patinated state (Normand 1986; Bon 2002; Séronie-Vivien et al. 2006; Chalard et al. 2010; Fernandes 2012) (Figs. 3e1, e2 and 4e).

The pelagic Salies-de-Béarn and Tercis flint types also belong to the Upper Cretaceous. The former, probably Campanian in age, outcrops in carbonated series in the Peyrehorade anticline (Orthez, Pyrénées-Atlantiques). They usually contain abundant bioturbations rich in relict carbonates, which give them a characteristic zoned appearance. From the micro-palaeontological viewpoint, they contain planktonic Globotruncana foraminifera (Normand 2002) (Figs. 3c and 4d). The latter, Campanian-Maastrichtian in age, outcrops in the proximity of the Avezac quarry (Tercis-les-Bains, Landes). Three varieties have been differentiated. They are generally translucent and bioclastic with a wackestone texture containing sponge spicules, algae (Pithonella) and planktonic and benthic foraminifera (Lagena) (Normand 2002; Fernandes 2012).

A further series of silicifications belongs to the Palaeocene. Urbasa flint is Thanetian in age and outcrops in limestone in the Urbasa mountain range (Navarre). It is characterised by the presence of benthic foraminifera of the Discocyclina (D. seunesi) and Nummulites ( $N$. heberti) genera, as well as echinoderms and incipient microdolomitisation (Figs. $3 \mathrm{f}$ and 4f) (Tarriño 2006; Tarriño et al. 2007). Another Flysch flint also dates from the Thanetian, the Artxilondo type (Irati, Navarre; Lecumberry, Pyrénées-Atlantiques). It resembles the Iholdy type, while also containing planktonic Globigerina foraminifera (Tarriño 2006). Loza flint is Thanetian-Ypresian in age (Palaeocene-Eocene) and outcrops in the calcareousdolomitic formations in the Loza-Moraza-Tobera ranges (Araba-Burgos). This translucent (chalcedonitic) raw material appears in nodules or mainly in silcretes that are usually fractured and display certain microdolomitisation, gypsum moulds and microgeodes (Tarriño 2006).

Finally, the Miocene Treviño varieties are Aquitanian in age. They outcrop in the carbonate formations in the Araico and Cucho-Busto ranges, in the tertiary Miranda-Treviño Depression (Araba-Burgos). They appear as both nodular and stratiform silicifications. Some varieties (especially the nodular ones) are characterised by characeous algae and fossils from continental environments, such as gastropods and ostracods, as well as by Liesegang rings (Figs. 3g1, g2 and 4g) (Tarriño 2006).

\section{Methodology}

This work is part of a comprehensive analysis of the aforementioned lithic assemblages, based on Analytical Typology (Laplace 1972). The present paper is dedicated to one of the aspects of this study, the raw materials. As it was clearly the most exploited resource during Upper Palaeolithic in the Western Pyrenees, the methodology focused on flint. This is based on the works carried out in this region by several authors like A. Tarriño, Ch. Normand, M. and M.-R. SéronieVivien and P. Fernandes, among others (see references cited in the 'Methodology' section). This study was concentrated on the macroscopic and microscopic textural analysis of the lithic remains ${ }^{1}$, identifying the different orthochemical

\footnotetext{
${ }^{1}$ All the remains were studied apart from the medial and distal fragments of knapping products (flakes, blades and bladelets), except for the assemblages from Ametzagaina and Usategi, which were studied in full. This was done to avoid over-representations. Within the electronic supplementary material, we include a table with the margins of error of the samples (Online Resource 1), which are appropriate in all cases.
} 
(crypto/microcrystalline quartz, carbonate relicts, etc.) and allochemical (dolomite crystals, quartz grains, fossils, etc.) components. In accordance with the characteristics described in the previous section (for further information, see the references cited), this allowed us to identify the type and variety of flint and, by extension, its geographic origin (outcrop or deposit). The remains that could not be assigned to a particular type for some reason (alterations, small size, unknown texture or characteristics, etc.) were included in the category of indeterminate. We also registered the degree of cortex and the post-diagenetic and post-depositional alterations. In the case of remains with cortex, its macroscopic particularities were also observed. For all this, we used a Kyowa SZM stereo microscope, with between $10 \times$ and $40 \times$ magnification. Observations at a higher magnification (up to $100 \times$ ) were sometimes necessary. The collection in the lithotheque in the Prehistory Area at the University of the Basque Country was consulted as a point of reference. Finally, the weight of all the flint remains was also recorded.

Regarding the scales of flint acquisition (if we consider the sites) and diffusion (if we consider the outcrops), we partially adopted the proposal of Tarriño et al. (2015). Thus, we considered that the local scale corresponds to the territory defined by a distance of up to $30 \mathrm{~km}$, the regional scale by a distance of $30-120 \mathrm{~km}$, and the supraregional scale (which would include the so-called tracer flints) by that which exceeds the barrier of $120 \mathrm{~km}$.

\section{Results}

As mentioned above, at all the sites flint was clearly the most abundant lithic resource (Table 3 ). The other raw materials included sandstone, lutite, limonite, limestone, gabbro, ophite, schist, rock crystal, quartz and quartzite.

\section{Bolinkoba, level VI/F}

Three main groups of raw materials were identified (Fig. 5 and Online Resource 2). The first is formed by the two main resources, Kurtzia Flysch and Treviño flint. By weight, the latter is the main flint type, while their representation is similar in terms of number of remains. A small percentage of the Flysch flint may be the Bidache type, bearing in mind the presence of other resources from north of the Western Pyrenees and the wide distribution of that type across the region in the Upper Palaeolithic. Great diversity is seen in the Treviño type, with the nodular micritic varieties most abundant. The silcrete varieties and such others as the algae banded variety appear in small numbers. Urbasa and Chalosse types form the second most numerous group. The two main varieties of Chalosse flint, Audignon and Bastennes-Gaujacq, are probably present, but this is still to be confirmed. The third group is formed by the Gaintxurizketa Flysch and Salies-de-Béarn types, with a minority presence. The indeterminate remains include three possible pieces of Loza flint, another three of the Tercis type, and one of a banded opaline beige flint, possibly of lacustrine origin, which may come from the south of the Massif Central in France (Tarriño, pers. com). Most cortical remains show a primary cortex. However, neocortex with stigma of abrasion (polish, shock traces as arcs, etc.) appear on a notable number of remains of Kurtzia Flysch (Online Resource 11).

\section{Amalda, levels VI and V}

In level VI (Fig. 6 and Online Resource 3), Flysch flint is by far the main type, in both number of remains and weight. The other types
Table 3 General quantitative data about the raw materials in the assemblages studied

\begin{tabular}{|c|c|c|c|c|c|c|c|}
\hline \multirow[t]{2}{*}{ Site } & \multirow[t]{2}{*}{ Level/assemblage } & \multirow[t]{2}{*}{ Total remains } & \multicolumn{2}{|c|}{$\begin{array}{l}\text { Number flint } \\
\text { remains }\end{array}$} & \multicolumn{2}{|c|}{$\begin{array}{l}\text { Number } \\
\text { analysed flint } \\
\text { remains }\end{array}$} & \multirow[t]{2}{*}{$\begin{array}{l}\text { Number remains } \\
\text { other raw mat. }\end{array}$} \\
\hline & & & & $\%$ & & $\%$ & \\
\hline Bolinkoba & $\mathrm{VI} / \mathrm{F}$ & 2506 & 2496 & 99.4 & 1714 & 68.7 & 10 \\
\hline \multirow[t]{2}{*}{ Amalda } & $\mathrm{V}$ & 829 & 805 & 97.1 & 467 & 58 & 24 \\
\hline & VI & 2264 & 2025 & 89.4 & 1220 & 60.2 & 239 \\
\hline Usategi & III + IV & 29 & 28 & 96.5 & 28 & 100 & 1 \\
\hline Ametzagaina & Eastern assemblage & 2436 & 2427 & 99.6 & 2427 & 100 & 9 \\
\hline \multirow[t]{4}{*}{ Aitzbitarte III } & III & 1534 & 1503 & 97.9 & 1038 & 69 & 31 \\
\hline & IV & 1045 & 1039 & 99.4 & 677 & 65.2 & 6 \\
\hline & $\mathrm{Va}$ & 921 & 918 & 99.7 & 637 & 69.4 & 3 \\
\hline & Upper Vb & 649 & 632 & 97.4 & 418 & 66.1 & 17 \\
\hline \multirow[t]{2}{*}{ Gatzarria } & Cbcs & 520 & 510 & 98.1 & 365 & 71.6 & 10 \\
\hline & & 12,733 & 12,383 & & 8991 & & 350 \\
\hline
\end{tabular}




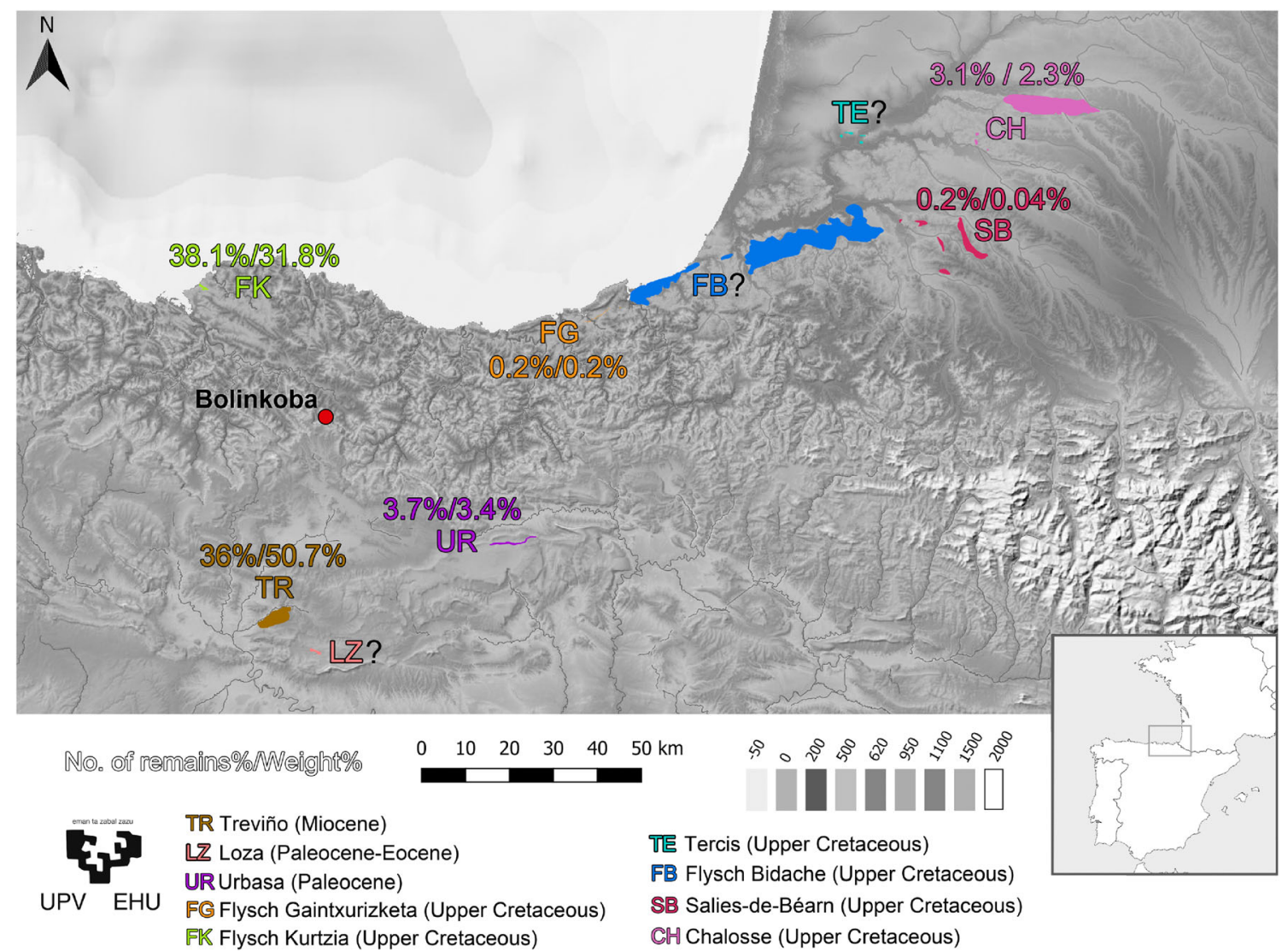

Fig. 5 Map with the outcrops exploited during the occupations in level VI/F at Bolinkoba, with the percentages of the raw materials as regards the number of remains and their weight

and varieties appear in very small percentages, and the Salies-deBéarn type is totally residual. This information must be nuanced, as the Flysch type is very probably represented by two varieties, Kurtzia and Bidache. Unlike the other sites, the outcrops of the two varieties are at similar distances from the cave (it is about $90 \mathrm{~km}$ on foot from Barrika and $75 \mathrm{~km}$ from the nearest outcrops in the Bidart area); therefore, the criterion of proximity cannot be applied to attribute the remains to one source or the others. Considering the presence of Gaintxurizketa Flysch flint, it is quite likely that the occupants of the cave also procured the proximate Bidache type, just as they could have acquired the Kurtzia flint. Therefore, as it is impossible to discriminate these varieties for certain without more detailed and destructive analyses, they must be grouped together. The Treviño flint includes mostly nodular micritic varieties, as well as the silcrete varieties. The indeterminate types include nine possible remains of Urgonian flint, three possible pieces of Tholdy Flysch flint and a possible remain of the Loza type. Finally, neocortex with marks of abrasion or erosion are visible on several pieces of Flysch flint, Gaintxurizketa Flysch, Urbasa and Chalosse flint (Online Resources 11 to 14), although most cortical remains have primary cortex.

In level V (Fig. 6 and Online Resource 4), the predominant type is again Flysch in terms of both variables. Urbasa, Chalosse, Treviño and Gaintxurizketa Flysch flint appear in small percentages although the latter gains in importance if the weight is considered. The Salies-de-Béarn type appears residually. As stated for level VI, the Flysch pieces probably correspond to both the Kurtzia and Bidache varieties. Nodular micritic and silcrete varieties were identified among the remains of Treviño flint. The indeterminates include a possible Urgonian specimen. Finally, neocortex with abrasion was also documented on several remains of Flysch flint, Gaintxurizketa Flysch and Chalosse flint (Online Resources 11, 12 and 14). Also in this case, most cortical remains show primary cortex.

\section{Usategi, levels III and IV}

The most abundant raw material is Urbasa flint, especially in level III (Table 4). The second most frequent type is Chalosse, and the third Flysch flint, probably of the Bidache type. This interpretation is based on several points: (1) the greater proximity of outcrops of this type (85 km on foot from Usategi) than the Kurtzia flint (about $100 \mathrm{~km})$; (2) the importance of Chalosse flint; and (3) the identification of a remain from a tabular nodule (and considering the texture and similar state of conservation, probably the three remains of this raw material), which is a common format in the Bidache type. The indeterminate 


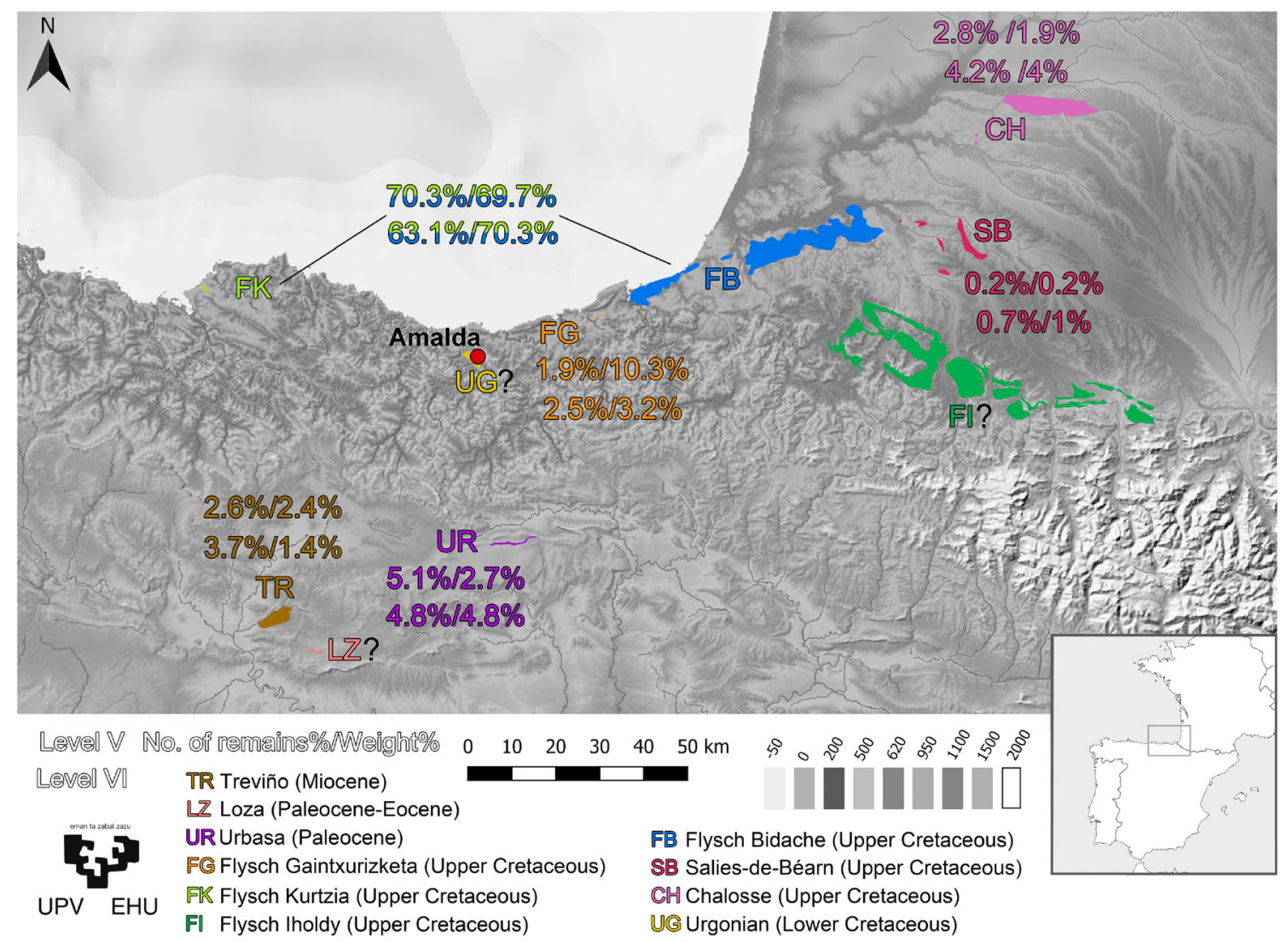

Fig. 6 Map with the outcrops exploited during the occupations in levels VI and V at Amalda, with the percentages of the raw materials as regards the number of remains and their weight

pieces include seven probable remains of Urbasa flint, one possible piece of Chalosse flint and another of the Treviño type (Fig. 7). Finally, it should be added that the neocortex on a piece of Chalosse flint displays marks of erosion (Online Resource 14).

\section{Ametzagaina, Eastern Assemblage}

In similar percentages, the main resources at this site were Gaintxurizketa Flysch and Bidache Flysch flint (Fig. 8 and Online Resource 5). The possibility that some of the remains of the last type really correspond to Kurtzia flint cannot be ruled out, although the scarcity of raw materials from the south side of the Western Pyrenees and the distance from the outcrops suggest that they will be scarce. The third most important type was Chalosse, followed by Urbasa flint in small numbers. The two main varieties of Chalosse flint, Audignon and Bastennes-Gaujacq, were identified, as well as two possible remains of the Salies-de-Béarn type. Although most cortical remains have primary cortex, marks of abrasion or erosion appear on neocortical surfaces of several pieces of Gaintxurizketa Flysch, Bidache Flysch and Chalosse flint, and with doubts Urbasa flint (Online Resources 11, 12 and 14).

\section{Aitzbitarte III, levels upper Vb, Va, IV and III (entrance sector)}

Considering the variables of number of remains and weight, the predominant type in level upper $\mathrm{Vb}$ (Figs. 9 and 10 and Online
Table 4 Number of remains of the flint types identified in levels III and IV at Usategi

\begin{tabular}{lllllll}
\hline & & Urbasa & Chalosse & Bidache Flysch & Indet. & Total \\
\hline \multirow{2}{*}{ Entrance } & Level III & 1 & 1 & 2 & - & 4 \\
& Level IV & - & 3 & - & - & 3 \\
\multirow{3}{*}{ Inner sector } & Level III & 8 & 3 & 1 & 9 & 21 \\
& Total & 9 & 7 & 3 & 9 & 28 \\
\hline
\end{tabular}




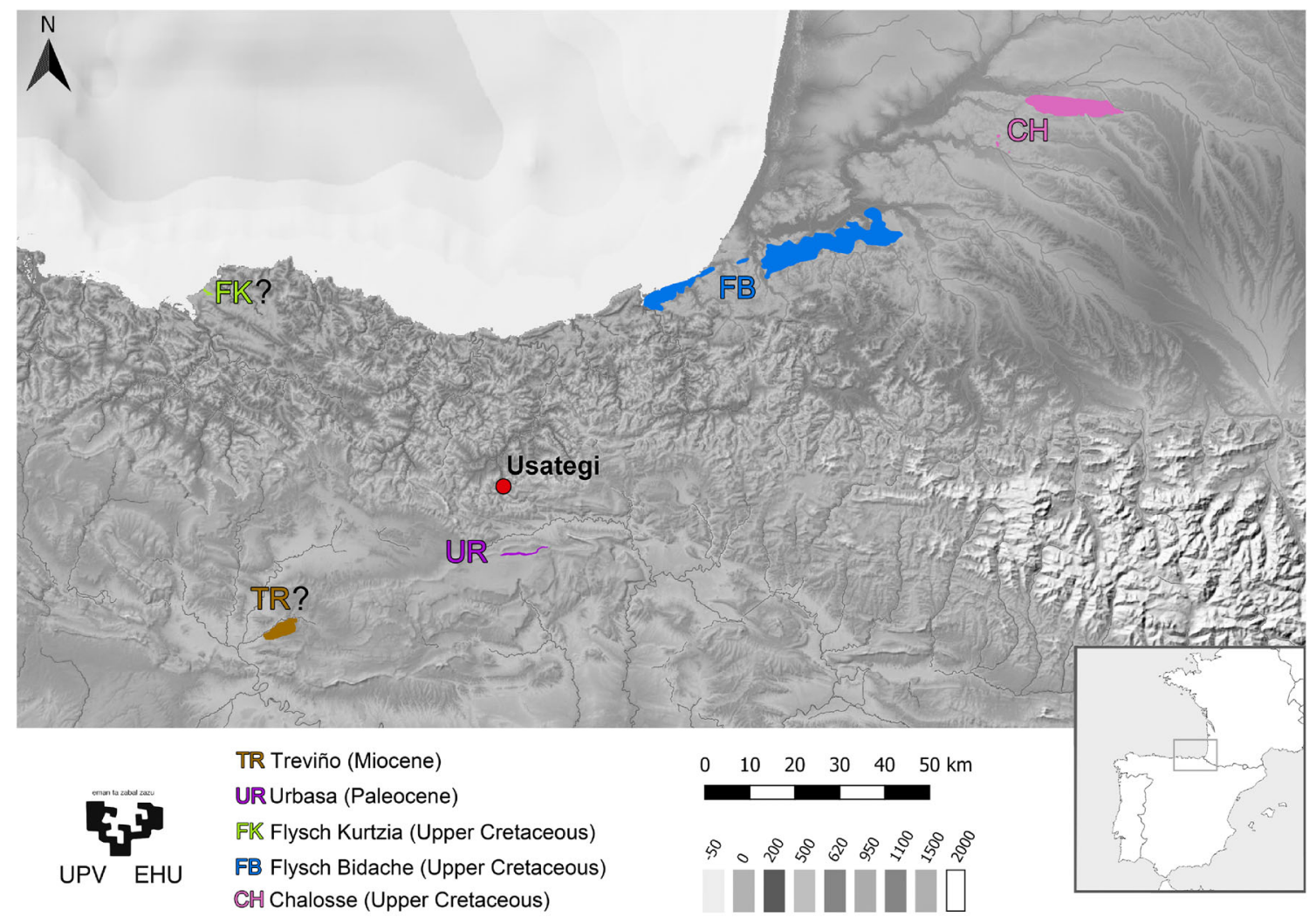

Fig. 7 Map with the outcrops exploited during the Gravettian occupations at Usategi

Resource 6) is Gaintxurizketa Flysch. The other two main resources vary in importance regarding the number of remains and their weight; in the number of remains, Bidache Flysch is the second most important flint, while in terms of weight, Urgonian flint is more important. It should be noted that a small percentage of the remains of the Bidache type may really correspond to the Kurtzia Flysch flint. Raw materials from Urbasa, Chalosse, Treviño and Salies-de-Béarn appear in small numbers. In the case of Treviño flint, mostly nodular micritic varieties but also silcrete ones were identified. Concerning Chalosse flint, the two varieties from Audignon and Bastennes-Gaujacq are probably present, but that could not be confirmed. Finally, a possible remain of Tercis flint was identified. Neocortex with abrasion or erosion was observed in several pieces of Bidache Flysch, Urbasa and Chalosse flint (Online Resources 11, 13 and 14). However, as with the other levels analysed, most cortical remains show primary cortex.

In level Va (Figs. 9 and 10 and Online Resource 7), the main raw material in terms of number of remains is Bidache Flysch. Again, a few specimens may belong to the Kurtzia type. It is followed by Gaintxurizketa Flysch and the Urgonian type (which increases its representation considerably if measured in terms of weight) and, in a third group, the Urbasa and Chalosse types. Salies-de-Béarn and Treviño flint are represented minimally. The Audignon and Bastennes-
Gaujacq varieties were documented among the Chalosse flint and mostly not only the nodular micritic variety but also silcrete in the Treviño type. Finally, four possible pieces of Tercis flint were recorded. Neocortical surfaces with abrasion or erosion marks were seen on several remains of the Bidache Flysch, Urbasa and Chalosse types (Online Resources 11, 13 and 14).

The distribution of raw materials in levels IV and III is similar, especially as regards the number of remains (Figs. 9 and 10 and Online Resource 8 and 9). Bidache Flysch is the best represented type in both of them. Bearing in mind the presence of resources from the south side of the Western Pyrenees, a few remains may correspond to the Kurtzia type. It is followed in importance by a second group consisting of Gaintxurizketa Flysch, Chalosse and Urbasa flint; considering weight, the latter increases its representation considerably in level IV. The next most important raw material was Urgonian flint which also increases its representation in terms of weight. Finally, Salies-de-Béarn and Treviño flint appear in minor amounts. Among Chalosse flint, the Audignon variety is present in both levels and Bastennes-Gaujacq only in level III. The Treviño type is mostly represented by nodular micritic varieties, while some silcrete remains have been identified and, with doubts, the 'algae banded' in level IV. A possible piece of Tercis flint was documented in level IV. Lastly, neocortex 


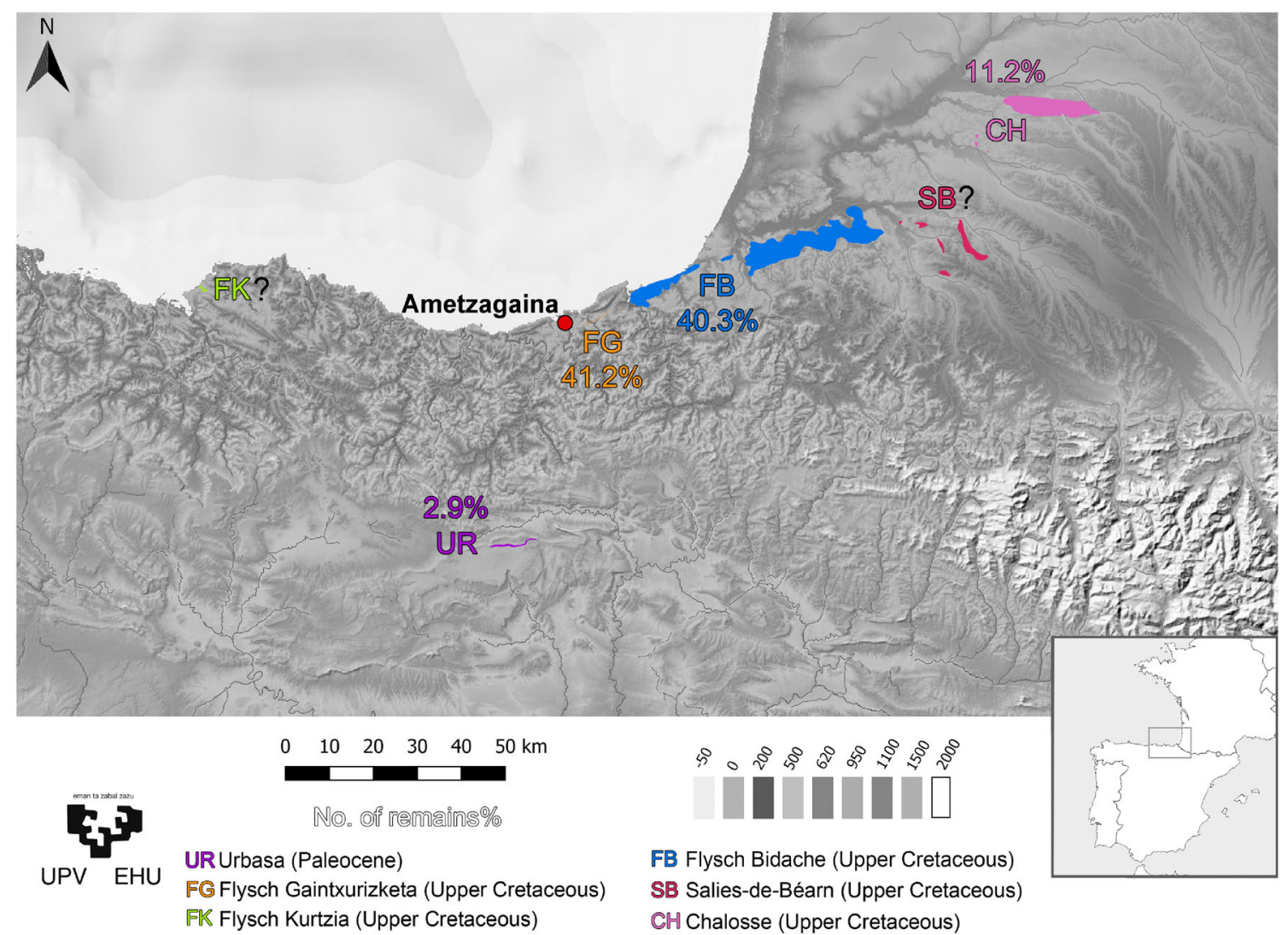

Fig. 8 Map with the outcrops exploited during the occupations in the eastern sector at Ametzagaina, with the percentages of the raw materials as regards the number of remains

with abrasion or erosion was observed on several remains of Bidache Flysch and Salies-de-Béarn flint in level IV and on Urbasa, Chalosse and perhaps Gaintxurizketa Flysch (also in level IV) (Online Resource 11 to 15).

\section{Gatzarria, level Cbcs}

Regarding level Cbcs at Gatzarria (Fig. 11 and Online Resource 10), it should be noted that the distribution of the different flint types and varieties varies enormously depending on the variable being considered. In terms of number of remains, the Bidache Flysch type is the most abundant, followed in importance by Chalosse, Salies-de-Béarn, Iholdy Flysch and Gaintxurizketa Flysch flint. In terms of weight, the most important raw material is Salies-de-Béarn flint, followed by Bidache Flysch, Iholdy Flysch, Chalosse and Gaintxurizketa Flysch. In any case, taking both variables into account, the best represented resource is Bidache Flysch followed by the Salies-de-Béarn type. Another group would include Chalosse and Iholdy Flysch flint, with finally a residual presence of Gaintxurizketa Flysch. Among the indeterminate flint, a few pieces might belong to the Urbasa and Tarté types (SéronieVivien et al. 2006), although this could not be confirmed. Lastly, outside the systematically analysed sample, a distal fragment of a micro-flake, probably knapping or retouching waste, was identified as belonging to the nodular micritic variety of Treviño flint, as well as another possible piece of Urbasa flint. We did not identify remains with neocortex with abrasion or erosion marks.

\section{Discussion}

\section{Lithic resource procurement patterns}

The most important lithic resources were the different Flysch flint types, especially the Bidache one. This was the main raw material on the northern side of the Western Pyrenees, ahead of other important types, such as Chalosse and Salies-deBéarn. This is seen at sites like Isturitz (Simonet 2010) and Alkerdi (Elorrieta 2015) and at those in the surroundings of the Bidache outcrops, where possible Gravettian sites have been identified (Colonge et al. 2015). It was also an important resource as sites in the Txingudi corridor (Ametzagaina and Aitzbitarte III), the main route between the two sides of the mountains although, geographically-speaking, it is located on the south side (see Fig. 1). On the rest of the southern side, Urbasa flint and, to a lesser extent, Treviño flint were 


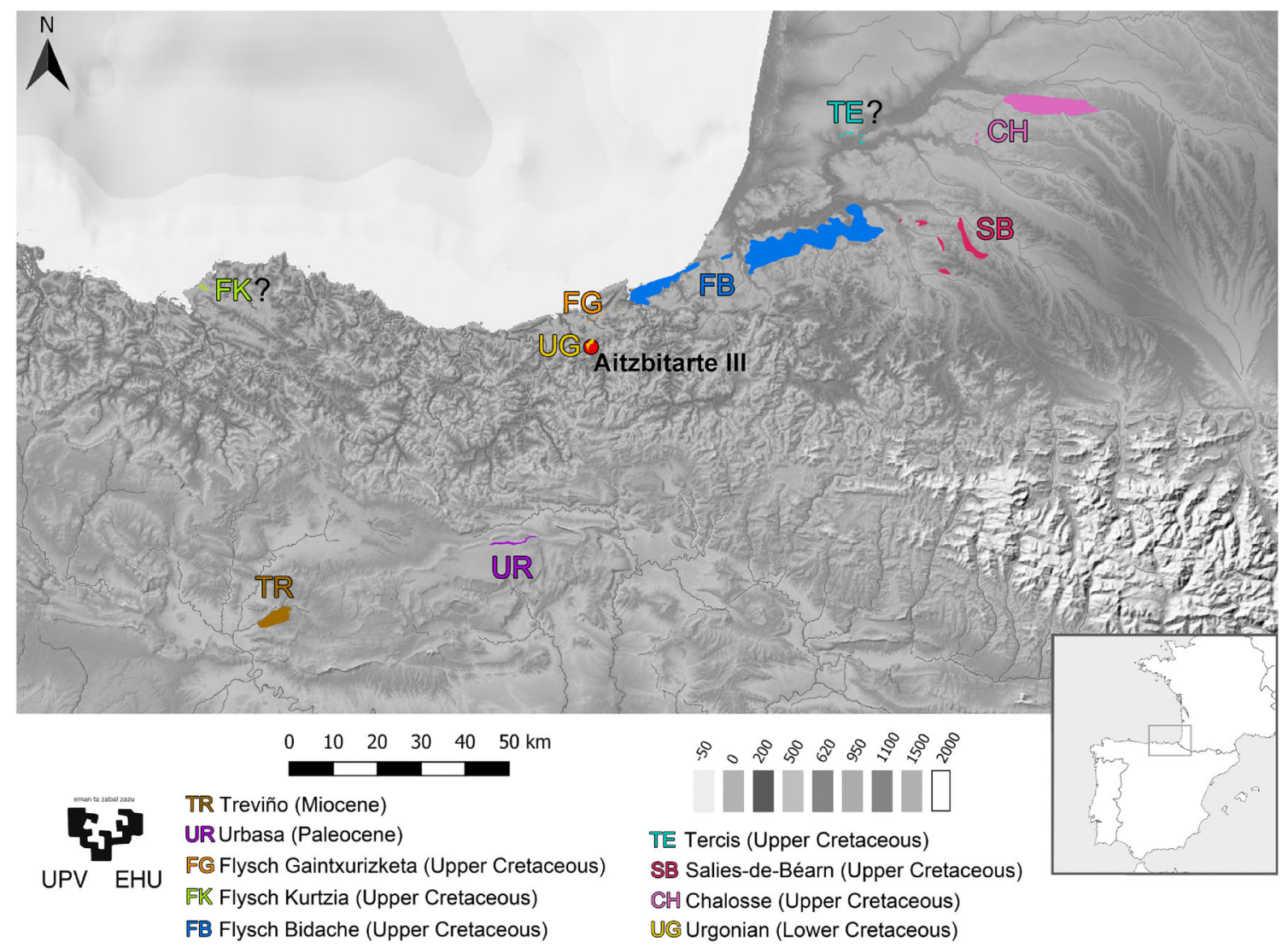

Fig. 9 Map with the outcrops exploited during the occupations in levels upper Vb, Va, IV and III in the entrance sector at Aitzbitarte III

important. The widespread distribution of this latter raw material should be noted, as it reached such distant sites as Grotte du Pape de Brassempouy (Simonet 2012a). The nodular varieties were clearly the most often used of the resources from Treviño. Despite the difficulty in discriminating Bidache and Kurtzia flint with the applied methods, it is evident that the latter Flysch type was also frequently used, as seen in the assemblage from Bolinkoba or the site of Antoliñako Koba, a few kilometres from its outcrops (Aguirre 2012). The other raw materials were less often used.

This considerable diversity of resources includes good quality flint for knapping but also others of 'intermediate' qualities and some very limited types. The first group is formed by the fine-grained homogeneous types from Treviño, Urbasa, Kurtzia, Bidache and Chalosse. In addition, these appear in formats suitable for blade knapping, as has been observed in different sites such as Prado, Mugarduia South, Le Prissé or Brassempouy, among others (Sáenz de Buruaga et al. 2005; Simonet 2012a; Aguirre 2013; Colonge et al. 2015). The second consists of Gaintxurizketa Flysch flint and the Salies-de-Béarn type. In both cases, the impurities of carbonate relicts would be an unfavourable component for knapping, in addition to the medium-sized grain that the former sometimes displays. The third group is represented by Urgonian flint and Iholdy Flysch flint, whose silicifications are usually fissured and in the form of small nodules (at Iholdy the nodules are under $10 \mathrm{~cm}$ long) that are often in inappropriate shapes for the technological requirements. In the case of the Iholdy type, another negative factor is its coarse grain.

This pattern reflects a diversified exploitation of lithic raw materials. However, the relationship between the accessibility of the outcrops and the distribution of the flint types in the different levels also shows that there was certain resource selection, so that those that most closely matched the techno-economic needs were acquired preferentially. In this sense, in practically all the assemblages it can be seen that the nearest or most accessible raw material to the site is more or less well represented but may not have been the most abundant or most intensely exploited flint. In these cases, the main resources were types of better quality or more appropriate for knapping, even though their outcrops were further away, at local and regional scales. This is quite evident not only at the sites of Aitzbitarte III and Gatzarria but also at Ametzagaina, where Bidache Flysch flint was reduced as much as or more intensely than Gaintxurizketa Flysch. A similar pattern has been observed as such sites as Isturitz (Lacarrière et al. 2011) and Alkerdi (Elorrieta 2015). The only exception is the assemblage in level IIbam at Zatoya, dominated by the mediocre local type of Artxilondo Flysch flint (Elorrieta 
Fig. 10 Doughnut charts with the distribution of flint types identified in levels upper $\mathrm{Vb}, \mathrm{Va}$, IV and III in the entrance sector at Aitzbitarte III, in terms of number of remains and weight

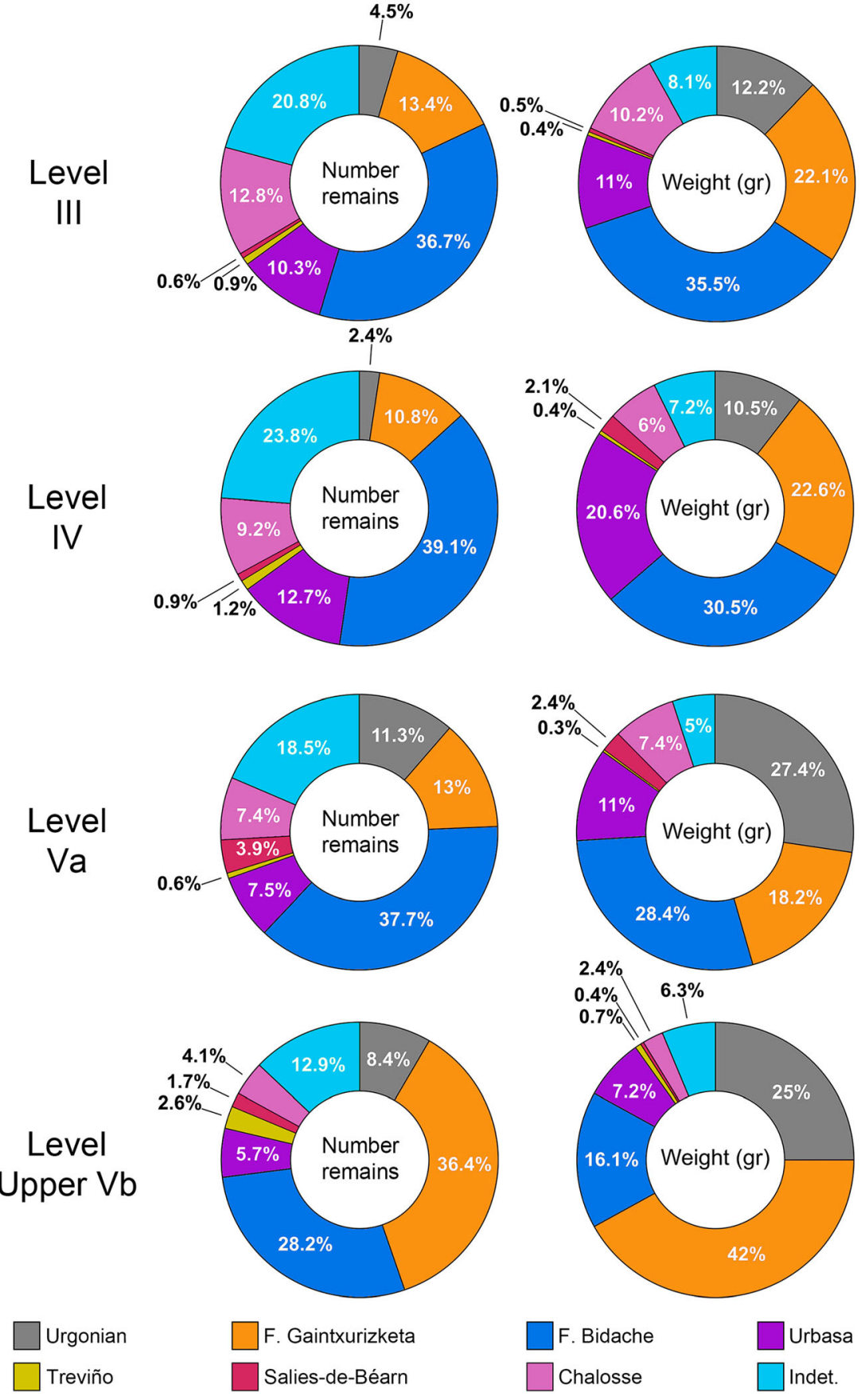

2015), which can probably be explained by the brevity of this seasonal occupation (Barandiarán and Cava 2008). A series of sites located near or on the outcrops of high-quality raw materials differ from this pattern, as those were logically the most used resources. Hence, the association between Antoliñako Koba and Kurtzia Flysch flint (Tarriño 2006), Mugarduia South and Urbasa flint (Tarriño 2013), Tercis and the homonymous type (Normand 1993; Simonet 2012b), Grotte du Pape de Brassempouy and Chalosse flint (Goutas and Simonet 2009; Simonet 2012a) and, perhaps (because of the more uncertain archaeological attribution), Le Prissé and Bidache
Flysch flint (Colonge et al. 2015) and Prado and the Treviño type (Sáenz de Buruaga et al. 2005). In the cases of Mugarduia South, Tercis, Le Prissé and Prado, one of their functions was that of a workshop for the systematic acquisition and exploitation of these local resources. Finally, a site that differs from all these patterns is the open-air site of Hin de Diou, where the local Chalosse and Tercis types are the least abundant in an assemblage dominated by the allochthonous Bidache Flysch and Salies-de-Béarn flint (Rémicourt et al. 2010). This underscores even more the central role of Bidache Flysch flint. 


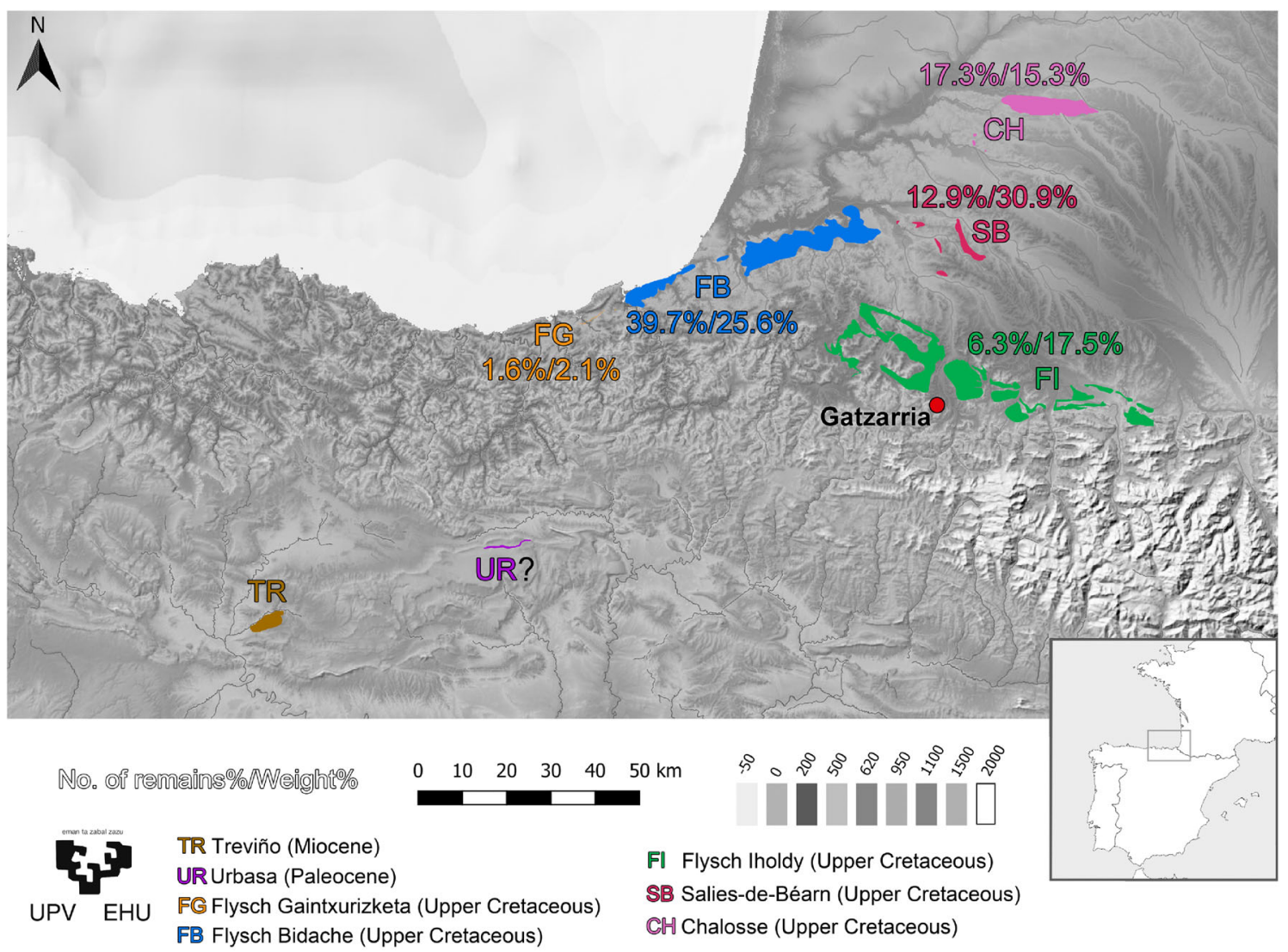

Fig. 11 Map with the outcrops exploited during the occupations in level Cbcs at Gatzarria, with the percentages of the raw materials as regards the number of remains and their weight

It can therefore be affirmed that during the period of study, the acquisition of lithic raw materials was guided by the criteria of quality and suitability for knapping rather than availability, accessibility or proximity. This pattern reveals that the Gravettian communities possessed exhaustive knowledge of the potential of each flint type and variety. It also implies foresight in the needs of supplies and the adaptation of mobility routes for that purpose. In this way, the procurement of lithic resources must have been a major activity within the economic organisation and exploitation of the territory.

Another interesting aspect is the presence of remains with neocortex displaying marks of erosion or of fluvial or marine abrasion in many of the assemblages. This shows that those nodules were probably obtained in secondary deposits, either colluvial, alluvial or coastal. This is usual in some Flysch types with outcrops on the coast or near it, as at Kurtzia. In this case, the sea erodes the deposit (an olistostrome) and the flint nodules are freed from it; then the waves rework them and accumulate them on the beach. A similar situation can be intuited in the case of the Bidache type and maybe Gaintxurizketa Flysch flint. In the case of Chalosse flint, these remains probably come from the sub-primary or secondary deposits situated on the flanks of the Audignon-Montaut anticline or from the colluvial deposits located in Sensacq, Bastennes-Gaujacq diapir (Fernandes 2012). However, evidence of erosion on flint types like Urbasa are less usual and harder to explain. In this case, the alteration may have been caused by colluvial or fluvial erosion. As proposed by Fernandes et al. (2008), procurement in those secondary deposits may have been casual and taken place in the course of other activities or simply while moving across the territory, with the exception of the Kurtzia and Chalosse outcrops. In any case, these possible deposits would have been of secondary importance, because remains with neocortex with abrasion or erosion are quantitatively less important than those with primary cortex and evidence of direct procurement at the primary outcrops is clear and abundant, as stated above.

\section{The socio-economic and territorial dimension of lithic resources}

\section{The Western Pyrenees as an economic territory}

Regarding the economic management of the territory, the present study has shown that the two sides of the Western 
Fig. 12 Histogram with the remains of raw materials from the north and south side of the Western Pyrenees in each of the levels and assemblages studied here. For the reasons given, indeterminate types and, in the case of Amalda, the Flysch flint, have been excluded percentages of the number of

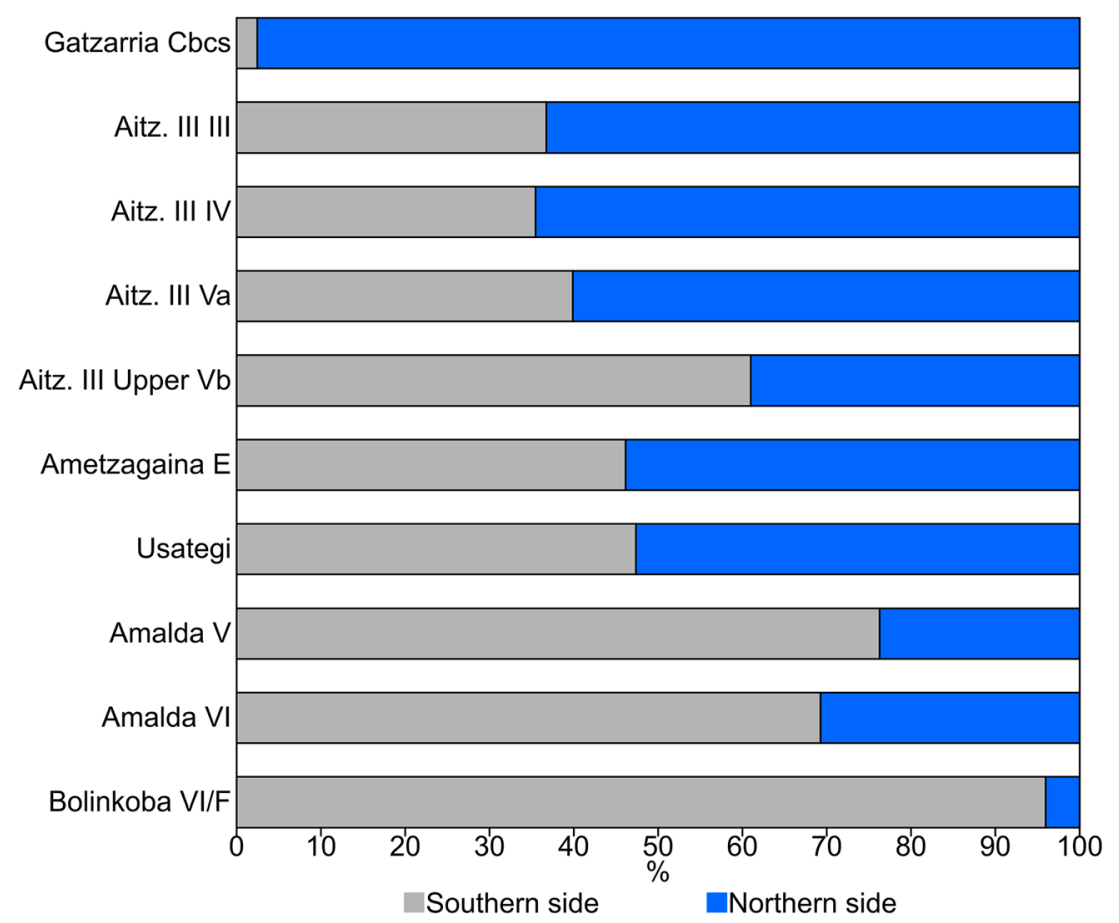

Pyrenees formed a defined and stable economic territory ${ }^{2}$ during the Gravettian, at least regarding lithic resources. The limits of this territory would be located in the outcrops of Kurtzia Flysch flint in the west, in the Chalosse outcrops to the north, the Artxilondo Flysch outcrops in the east and in the sources of Treviño flint in the south. This is shown by the possible presence of Kurtzia Flysch flint at Ametzagaina, the Chalosse type at Usategi and Bolinkoba, Artxilondo Flysch at Zatoya (Elorrieta 2015) and Treviño flint at Gatzarria and Grotte du Pape de Brassempouy (Simonet 2012a).

However, in the internal structure of this territory, a more or less significant quantitative or qualitative imbalance can be observed at sites on each side of the Western Pyrenees regarding resources from the other side. That is to say, the importance of raw materials from the north at sites in the south is greater than inversely (Fig. 12). This is because of the central role of Bidache Flysch flint and the wide geographic distribution of Chalosse flint. This is seen clearly at Usategi and the sites in the Txingudi corridor, where those northern resources are predominant. This is highly significant, as in both cases outcrops like Urbasa would have been more easily accessible than, for example, those of Chalosse (Sánchez et al. 2016).

Information from other Gravettian lithic assemblages seems to support this idea. Thus, at sites to the north, like Alkerdi, Isturitz and Grotte du Pape de Brassempouy, resources from the south are quantitatively unimportant or

\footnotetext{
${ }^{2}$ In this case, we understand as economic territory the geographical space comprised by the aggregate of abiotic resources exploited by the human communities that inhabited it.
}

insignificant (Lacarrière et al. 2011; Simonet 2012a; Elorrieta 2015), while at such others as Hin de Diou, Tercis and Le Prissé, they are totally absent (Rémicourt et al. 2010; Simonet 2012b; Colonge et al. 2015). The proximity of some of these to the Txingudi corridor makes this aspect even more evident. The case of the open-air workshop of Mugarduia South, located near the Urbasa flint outcrop, is quite striking. Although resources from the north are quite scarce (Tarriño 2013), their existence contrasts significantly with the pattern at workshops in the north, like those at Tercis and Le Prissé. Similarly, in level IIbam at Zatoya, the second more frequent raw material was the Bidache Flysch type rather than Urbasa flint, while a few remains of Chalosse flint were also documented (Elorrieta 2015). The presence of these resources from the north is quite revealing, owing to the location of the cave in the foothills on the southern side of the mountains.

Thus, it seems that links between sites in the south with outcrops in the north are stronger than inversely. As explained, to the extent that raw material procurement patterns are connected to mobility patterns and the economic management of the territory, this asymmetry could be evidence for differences in the economic, territorial and functional roles of each side of the Western Pyrenees. If that is correct, one possible interpretation is that the sites on the southern side may, in general terms, have been related more closely with logistic or seasonal activities (Barandiarán and Cava 2008). In contrast, the role of the north side would have been more residential with more continuous occupation during the whole year. Therefore, the occupations in the north would have produced richer archaeological sequences, in both quantitative and qualitative terms. This is 
Fig. 13 Diagram showing the relationships between the different economic territories. The sites related to the contacts between groups, while the others refer to the evidence of those contacts, either lithic raw materials (purple dots) or other resources (light blue dot). The areas of dispersion of the main elements in the material culture of the Gravettian technocomplex are also shown green dots represent the possible

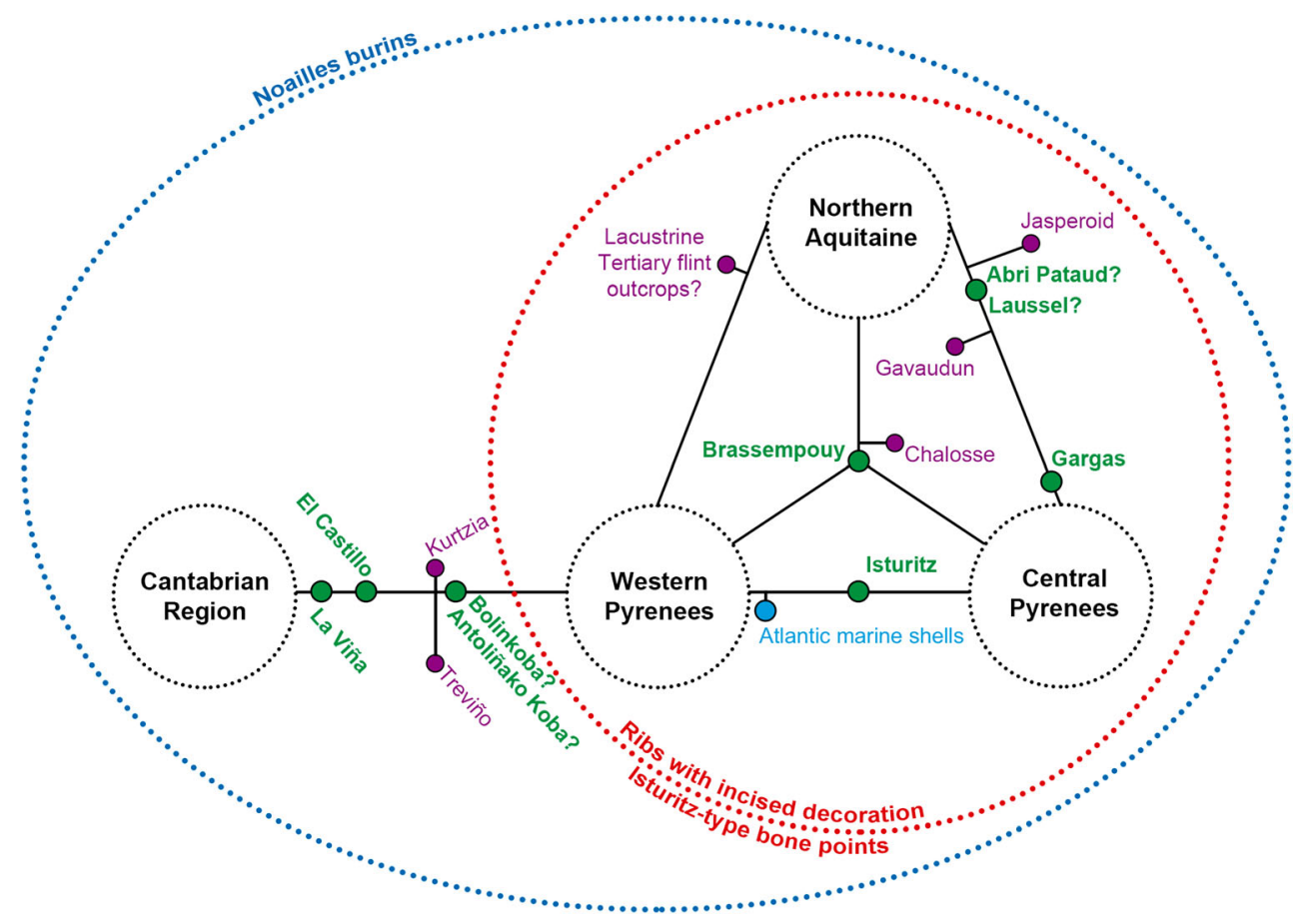

Towards the Gravettian economic mosaic

seen in the archaeological records at the sites of Isturitz and Brassempouy, which clearly contrast with the more modest sites in the south. If the former acted as large residential settlements or aggregation sites, the latter would have been used for more specialised or sporadic functions (Simonet 2017).

The interpretation of the origin of this hypothetical functional dichotomy is not simple. Seasonal movements from the north to the south, possibly motivated by the migrations of ungulates (mainly reindeer but also bison) or other causes connected with subsistence (plant and/or marine resources) might explain it. In this regard, seasonality data for ungulate fauna hunted during the Gravettian occupations in level IV at Isturitz show that reindeer and horses were hunted all year, although reindeer hunting was less intense and horses were not captured in summer and early autumn. Bison were hunted most in autumn and early winter (Normand et al. 2012). In contrast, faunal data from levels VI and V at Amalda, Ilbam at Zatoya and levels Va and IV at Aitzbitarte III show that those caves were occupied in summer and/or autumn, although there is some evidence of possible occupations at other times of the year at the latter site (Yravedra 2007; Barandiarán and Cava 2008; Altuna and Mariezkurrena 2001; Altuna and Mariezkurrena 2011). Reindeer has been documented in the fauna from levels VI at Amalda and Va, IV and III at Aitzbitarte III, as well as in level V/E at Bolinkoba (Gómez-Olivencia et al. 2014). Remains of a mackerel were found in level Va at Aitzbitarte III, which suggests late spring and summer (Roselló and Morales 2011). Finally, bovines are present in all the faunal assemblages. These scarce data are generally in accordance with the proposed hypothesis, although this must still be regarded as tentative.
From a wider perspective, the economic territory of the Western Pyrenees maintained connections with surrounding areas, and these are mainly represented by resources from common outcrops. Towards the east, in the central Pyrenees, data from Gargas, Enlène and La Tuto de Camalhot trace out another territory characterised by the use primarily of local flint types from the central sector of the mountain range (Foucher et al. 2011; Foucher 2015, 2016). At Gargas, allochthonous raw materials come from the departments of Lot and Garonne and Dordogne to the north, and probably from the Chalosse area to the west and the Ebro valley to the south. In this sense, the presence in this cave of Atlantic marine shells confirms the contact of its inhabitants with the Western Pyrenees (Foucher 2004; Foucher 2006; Foucher and San Juan-Foucher 2008). Towards the west, in the centralwestern sector of the Cantabrian Region, a different economic territory is marked by the use of other local rocks, such as quartzite, rock crystal and radiolarite (especially in the west) and several local and regional flint types. They were complemented by variable amounts of allochthonous flint from the western end of the Western Pyrenees, such as the Kurtzia Flysch and Treviño flint types, which have been documented at sites like La Viña, Altamira, Morín and El Mirón (de las Heras et al. 2012; González-Morales and Straus 2013; Bradtmöller 2015; Martínez 2015). Towards the north-east, sites in north Aquitaine belong to an economic territory defined by the use of flint from the Dordogne and Vézère river basins (Chiotti et al. 2004; Morala 2017). Exotic resources 
identified at the sites of Les Fieux and Laugerie-Haute-Est include pieces of flint with Lepidorbitoides, which may come from the Chalosse outcrops ${ }^{3}$ (Chalard et al. 2006; Guillermin 2008; Chalard et al. 2010; Chiotti et al. 2018).

Therefore, tracer or widely distributed flint, like the Chalosse, Kurtzia Flysch or Treviño types may have been exchanged with groups from different territories. This could have taken place periodically at certain aggregation sites (Fig. 13). As we have seen, Chalosse flint represents possible connections between the Western Pyrenees, the central Pyrenees and north Aquitaine. Owing to its proximity to these outcrops and its archaeological record, Grotte du Pape de Brassempouy may have been one of those aggregation sites (Simonet 2017). Its alleged duality as a dwelling and ritual site may be connected with that role (Goutas and Simonet 2009; Simonet 2012c). Another aggregation site, which is often proposed, is Isturitz. This cave could have been a meeting place for groups from the south side of the Western Pyrenees (and even from the centre and west of the Cantabrian Region) and the Central Pyrenees (Foucher and San Juan-Foucher 2008). If confirmed in the future, the remain from level VI/F at Bolinkoba from tertiary outcrops in the south of the Massif Central in France would provide further evidence of a connection between the Western Pyrenees and northern Aquitaine (Chiotti et al. 2004). Finally, although there is no direct evidence of links between the territories of the Western Pyrenees and the Ebro valley, one of the few Gravettian sites is Fuente del Trucho, where parietal hand stencils would be the main indicator of a connection, which might be extended to the other territories that have been mentioned (Hoffmann et al. 2017).

Apart from their evident and proven economic role, the social role played by tracer flint types should also be emphasised. They at least appear to be clear evidence of contacts between groups, which were probably vital in the articulation or socio-cultural cohesion of the human communities involved. In this sense, it may be supposed that in addition to those material exchanges there were others of an intangible nature (Homans 1958), perhaps represented by expressions such as Venus figurines or hand stencils, among others.

These aspects acquire greater interest if they are related to other parts of the archaeological record (Fig. 13). The territories that have been cited belong to the distribution of the Gravettian with Noailles burins, including such key sites as La Viña, Bolinkoba, Isturitz, Gargas and Pataud, among others. At the same time, in the Western and Central Pyrenees and the north of Aquitaine, other elements units those territories, such as ribs

\footnotetext{
3 Although likely, the Chalosse origin of the flint with Lepidorbitoides is not totally confirmed, as other outcrops of raw materials with these fossils are known in the Central Pyrenees (River Boussens) and in the south of the Gers department. This is also the case of Gargas (Foucher et al. 2016). However, as seen before movements and contacts of the groups that occupied this cave with the Western Pyrenees are well documented, and therefore, it is very likely that some of these lithic resources do come from the Chalosse area.
}

with incised decoration (of the 'type 2', sensu San JuanFoucher) as found at Bolinkoba, Isturitz, Gargas, Brassempouy and Fourneau du Diable, and the Isturitz-type bone points, documented at the above sites (except for Fourneau du Diable) and such others as Usategi, Aitzbitarte III, Téoulé, Abri Pataud and Roc de Combe (San Juan-Foucher and Vercoutère 2003; San Juan-Foucher 2013). Thus, these objects define two 'cultural tesseras': a wider one, characterised by Noailles burins, and a narrower one, determined by those tools and the mentioned ones from the bone industry. These 'cultural tesseras' of the Gravettian mosaic are structured internally around different economic territories (or 'economic tesseras') related to the distribution of lithic resources. This would suggest the existence of an economic mosaic imbricated with a cultural one. In this sense, each of the different economic territories would have been managed and exploited by specific human communities, all of them culturally linked.

\section{Conclusions}

The determination of the provenance of lithic raw materials exploited in ten levels or assemblages has provided valuable information about the procurement patterns of those resources and the economic organisation of the territory by the human communities living in the Western Pyrenees between ca. 31 and $21 \mathrm{ky}$ BP (35-25 ky cal. BP). In the first place, the flint types were very diverse and ranged from high-quality material for lithic reduction to poorer types. Overall, the most important raw materials were Flysch flint, especially the Bidache type (in the north) and Kurtzia type (in the south). Chalosse, Urbasa and Treviño flints were also important resources on their respective sides of the mountain range. This pattern was defined by the criteria of quality and suitability for knapping rather than by availability, accessibility or proximity. This must imply that the communities possessed exhaustive knowledge of the characteristics and potential of each flint type and variety and that they were aware of the need for supplies and adapted their mobility routes for that purpose. Procurement usually took place at the primary outcrops, although a small part (except in the cases of Kurtzia Flysch flint and Chalosse flint) may have come from secondary coastal, colluvial or alluvial deposits.

These results show that the Western Pyrenees was a defined and stable economic territory during the Gravettian. The closer link of raw materials from the north with sites in the south may be evidence of different economic, territorial or functional roles of each side. In general terms, the south side may have been more closely related to logistic or seasonal activities, whereas the north would have played a more residential role with more continual occupation throughout the year. This relationship may be associated with seasonal movements due to the migration of some ungulates or other causes 
connected with subsistence. This hypothesis, still tentative, should be explored and tested by future research.

The Western Pyrenees was linked to other surrounding economic territories, as demonstrated by the distribution of tracer flint types, like Chalosse or Kurtzia Flysch. These resources may have been exchanged (at least partially) among the human groups at aggregation sites like El Castillo, Isturitz and Brassempouy, or at least they seem to be evidence of contact between those groups. In this way, two territorial mosaics were superimposed, as the economic mosaic was imbricated with a cultural or symbolic one.

In the immediate future of research, it will be necessary to continue with the lithic raw material provenance analyses, especially as regards sites on the north side of the mountain range and the centre and western sectors of the Cantabrian Region. A specific study of possible secondary deposits would also be interesting, owing to their importance at other Palaeolithic contexts and in connection with other resources, such as quartzite (Prieto 2018). In connection with this, another objective will be a more detailed analysis of cortical remains at these and other sites, as they can provide more information about the nature and origin of lithic raw materials (Fernandes 2012). We would also like to explore more precisely the issue about the quality of the different flint types and varieties. Finally, further information about the seasonality of occupations will enable more consistent assessment of the hypothesis about seasonal movements from one side of the Western Pyrenees to the other.

Supplementary Information The online version contains supplementary material available at https://doi.org/10.1007/s12520-020-01231-x.

Acknowledgements This paper comes from the $\mathrm{PhD}$ thesis of A. Calvo. For this reason, he would like to express his gratitude to his two supervisors, Alvaro Arrizabalaga and Pascal Foucher. The authors would like to thank Andoni Tarriño for his help in the raw material analysis, Maite García-Rojas for the preparation of the base maps and Alejandro Prieto for his valuable comments on the paper. Finally, we would like to thank the two anonymous reviewers for their comments and suggestions.

Funding Open Access funding enabled and organized by Projekt DEAL. This research was partially supported by the project HAR2017-82483C3-1-P, financed by the Spanish Ministry of Science and the Consolidated Research Group in Prehistory of the University of the Basque Country (IT-1223-19). A. C. is funded by the Education Department of the Government of the Basque Country through a postdoctoral fellowship (POS_2019_1_0017).

Data Availability Not applicable.

\section{Compliance with ethical standards}

Conflict of interest The authors declare that they have no conflicts of interest.

Code availability Not applicable.
Open Access This article is licensed under a Creative Commons Attribution 4.0 International License, which permits use, sharing, adaptation, distribution and reproduction in any medium or format, as long as you give appropriate credit to the original author(s) and the source, provide a link to the Creative Commons licence, and indicate if changes were made. The images or other third party material in this article are included in the article's Creative Commons licence, unless indicated otherwise in a credit line to the material. If material is not included in the article's Creative Commons licence and your intended use is not permitted by statutory regulation or exceeds the permitted use, you will need to obtain permission directly from the copyright holder. To view a copy of this licence, visit http://creativecommons.org/licenses/by/4.0/.

\section{References}

Aguirre M (2012) Ocupaciones gravetienses de Antoliñako koba: aproximación preliminar a su estratigrafía, cronología e industrias. In: de las Heras C, Lasheras JA, Arrizabalaga A, de la Rasilla M (eds) Pensando el Gravetiense: nuevos datos para la Región Cantábrica en su contexto peninsular y pirenaico. Museo Nacional y Centro de Investigación de Altamira, Madrid, pp 229-242

Aguirre M (2013) Caracterización tecnológica de la industria lítica de Mugarduia Sur (Urbasa, Navarra). In: Barandiarán I, Cava A, Aguirre M (eds) El taller de sílex de Mugarduia Sur: una ocupación de Urbasa (Navarra) durante el Gravetiense. University of the Basque Country, Vitoria-Gasteiz, pp 401-524

Altuna J (1992) Dataciones de radiocarbono para el Perigordiense Superior del País Vasco. Munibe (Antropologia-Arkeologia) 43: $31-32$

Altuna J (2011) Aitzbitarte III situación. Descripcion del valle y de la cueva. Historia de las excavaciones recientes. Descripción del relleno (Zona de Entrada). Dataciones de radiocarbono. In: Altuna J, Mariezkurrena K, Rios-Garaizar J (eds) Ocupaciones humanas en Aitzbitarte III (País Vasco). 33.600-18.400 BP (Zona de entrada a la cueva). Gobierno Vasco, Vitoria-Gasteiz, pp 25-38

Altuna J, Mariezkurrena K (2001) Restos de macromamíferos del yacimiento de Zatoya (Navarra). Trab Arqueol Navarra 15:101-114

Altuna J, Mariezkurrena K (2011) Estudio de los macromamíferos del yacimiento de Aitzbitarte III (Excavación de la entrada). In: Altuna J, Mariezkurrena K, Rios-Garaizar J (eds) Ocupaciones humanas en Aitzbitarte III (País Vasco). 33.600-18.400 BP (Zona de entrada a la cueva). Gobierno Vasco, Vitoria-Gasteiz, pp 395-480

Aranburu A (1998) El Aptiense-Albiense de Trucíos-Güeñes (Oeste de Bizkaia). Dissertation, University of the Basque Country

Arrizabalaga A (1994) Individualización morfológica de los buriles gravetienses. El "Noaillense" de Bolinkoba (Abadiño, Bizkaia). Munibe (Antropologia-Arkeologia) 46:33-51

Arrizabalaga A, Calvo A, Elorrieta I, Tapia J, Tarriño A (2014) Where to and what for? Mobility patterns and the management of lithic resources by Gravettian hunter-gatherers in the western Pyrenees. J Anthropol Res 70(2):233-261. https://doi.org/10.3998/jar.0521004. 0070.204

Aubry T, Mangado J, Fullola JM, Rosell L, Sampaio JD (2004) The raw material procurement at the Upper Palaeolithic settlements of the Côa Valley (Portugal): new data concerning modes of resource exploitation in Iberia. In: Smyntyna OV (ed) The use of living space in prehistory: papers from a session held at the European Association of Archaeologists Sixth Annual Meeting in Lisbon 2000. Archaeopress, Oxford, pp 37-50

Aubry T, Luís L, Mangado Llach J, Matias H (2012) We will be known by the tracks we leave behind: exotic lithic raw materials, mobility and social networking among the Côa Valley foragers (Portugal). J Anthropol Archaeol 31(4):528-550. https://doi.org/10.1016/j.jaa. 2012.05.003 
Barandiarán I (1980) Auriñaciense y Perigordiense en el País Vasco: estado actual. Munibe (Antropologia-Arkeologia) 3-4:325-333

Barandiarán I, Cava A (2008) Identificaciones del Gravetiense en las estribaciones occidentales del Pirineo: modelos de ocupación y uso. Trab Prehist 65(1):13-28

Blades BS (1999) Aurignacian lithic economy and early modern human mobility. J Hum Evol 37:91-120. https://doi.org/10.1006/jhev. 1999.0303

Bon F (2002) Les ressources en silex de la Chalosse centrale: gîtes et ateliers du dôme diapir de Bastennes-Gaujacq et de l'anticlinal d'Audignon. In: Cazals N (ed) Comportements techniques et économiques des societies du Paléolithique supérieur dans le context pyrenéen, Project Collectif de Recherche 2002. Service Regional de l'Archéologie de Midi-Pyrénées, Toulouse, pp 47-63

Bon F, Chauvaud D, Dartiguepeyrou S, Gardere P, Mensan R (1996) La caractérisation du silex de Chalosse. Antiq Natl 28:33-38

Bradtmöller M (2015) The Gravettian occupation of level 4 at Cueva Morín (Cantabrian Region) and its regional context. Munibe (Antropologia-Arkeologia) 66:23-52. https://doi.org/10.21630/ maa.2015.66.02

Calvo A (2019) The Gravettian in the western Pyrenees: dynamics of procurement and technological management of lithic raw materials. Dissertation, University of the Basque Country

Calvo A, Prieto A (2012) El final del Gravetiense y el comienzo del Solutrense en la Península Ibérica. Un estado de la cuestión acerca de la cronología radiocarbónica en 2012. Espac Tiempo y Forma Ser I, Nueva época Prehist y Arqueol 5:131-148

Calvo A, Tapia J, Arrizabalaga A, Iriarte-Chiapusso MJ (2013) El yacimiento de Ametzagaina (Donostia, País Vasco). Un campamento Gravetiense al aire libre en el Cantábrico In: de las Heras C, Lasheras JA, Arrizabalaga A, de la Rasilla M (eds) Pensando el Gravetiense: nuevos datos para la Región Cantábrica en su contexto peninsular y pirenaico. Museo Nacional y Centro de Investigación de Altamira, Madrid, pp 229-240

Calvo A, Perales U, García-Rojas M, Normand C, Arrizabalaga A (2019) Just before sewing needles. A functional hypothesis for Gravettian Noailles-type burins from Isturitz cave (Basque Country, southwestern France). J Archaeol Sci Rep 25:420-432. https://doi.org/10. 1016/j.jasrep.2019.04.022

Chalard P, Guillermin P, Jarry M (2006) Acquisition et exploitation des silex allochtones au Gravettien. L'exemple de la couche E du gisement des Fieux (Lot, France). In: Bressy C, Burke A, Chalard P, Martin H (eds) Notions de Territoire et de Mobilité: Exemples de l'Europe et Des Premières Notions En Amérique Du Nord Avant Le Contact Européen. Université de Liège, Liège, pp 29-40

Chalard P, Bon F, Bruxelles L, Ducasse S, Teyssandier N, Renard C, Gardere P, Guillermin P, Lacombe S, Langlais M, Mensan R, Normand C, Simonnet R, Tarriño A (2010) Chalosse type flint: exploitation and distribution of a lithologic tracer during the Upper Paleolithic, Southern France. In: Brewer-LaPorta M, Burke A, Field $\mathrm{D}$ (eds) Ancient mines and quarries: a trans-Atlantic perspective. Oxbow Books, Oxford, pp 13-22

Chiotti L, Nespoulet R, Pottier C (2004) Contribution des collections du Paléolithique supérieur de l'abri Pataud (Les Eyzies-de-Tayac, Dordogne, France) à la connaissance de la gestion des matières premières siliceuses dans le nord de l'Aquitaine. In: Actes du XIVème Congrès UISPP, Université de Liège, Belgique, 2-8 Septembre 2001. Archaeopress, Oxford, pp 73-82

Chiotti L, Morala A, Nespoulet R (2018) Usages domestiques et symboliques du minéral au Gravettien final. Abri Pataud Laugerie-Haute Est - Les Peyrugues. Musée National de Préhistoire, Les Eyzies-de-Tayac-Sireuil

Colonge D, Claud E, Deschamps M, Fourloubey C, Hernandez M, Sellami F, Anderson L, Busseuil N, Debenham N, Garon H, O'Farrel M (2015) Preliminary results from new Palaeolithic open-air sites near Bayonne (south-western France). Quat Int 364: 109-125. https://doi.org/10.1016/j.quaint.2014.12.007

de las Heras C, Montes R, Lasheras JA (2012) Altamira: nivel gravetiense y cronología de su arte rupestre. In: de las Heras C, Lasheras JA, Arrizabalaga A, de la Rasilla M (eds) Pensando el Gravetiense: nuevos datos para la Región Cantábrica en su contexto peninsular y pirenaico. Museo Nacional y Centro de Investigación de Altamira, Madrid, pp 476-491

Elorrieta I (2015) Aprovisionamiento y disponibilidad de las materias primas silíceas en el Pirineo Occidental durante el Paleolítco Superior. Dissertation, University of the Basque Country

Elorza J, Bustillo MA (1989) Early and late diagenetic chert in carbonate turbidites of the Senonian Flysch, Northeast Bilbao, Spain. In: Hein JR, Obradovic J (eds) Siliceous deposits of the Tethys and Pacific regions. Springer-Verlag, New York, pp 93-106

Fernandes P (2012) Itinéraires et transformations du silex: une pétroarchéologie refondée, application au Paléolithique moyen. University of Bordeaux I, Dissertation

Fernandes P, Raynal JP, Moncel MH (2008) Middle Palaeolithic raw material gathering territories and human mobility in the southern Massif Central, France: first results from a petro-archaeological study on flint. J Archaeol Sci 35(8):2357-2370. https://doi.org/10. 1016/j.jas.2008.02.012

Fontes LM, Straus LG, González Morales MR (2016) Lithic raw material conveyance and hunter-gatherer mobility during the Lower Magdalenian in Cantabria, Spain. Quat Int 412:66-81. https://doi. org/10.1016/j.quaint.2015.09.017

Foucher P (2004) Les industries lithiques du complexe GravettienSolutréen dans les Pyrénées: techno-typologie et circulation des matières siliceuses de part et d'autre de l'axe Pyrénées-Cantabres. Dissertation, University of Toulouse II-Le Mirail

Foucher P (2006) Gargas et l'Atlantique: les relations transpyrénéennes au cours du Gravettien. Munibe (Antropologia-Arkeologia) 57(2): $131-147$

Foucher P (2015) Flint economy in the Pyrenees: a general view of siliceous raw material sources and their use in the Pyrenean Gravettian. J Lithic Stud 2(1):111-129. https://doi.org/10.2218/jls. v2i1.1306

Foucher P, San Juan-Foucher C (2008) Du silex, de l'os et des coquillages : matières et espaces géographiques dans le Gravettien pyrénéen. In: Aubry T, Almeida F, Araújo AC, Tiffagom M (eds) International Union for Prehistoric and Protohistoric Sciences. Proceedings of the XV World Congress (Lisbon, 4-9 September 2006). Archaeopress, Oxford, pp 45-55

Foucher P, San Juan-Foucher C, Oberlin C (2011) Les niveaux d'occupation gravettiens de Gargas (Hautes-Pyrénées): nouvelles données chronostratigraphiques. In: A la recherche des identités gravettiennes: actualités, questionnements et perspectives. Actes de la table ronde d'Aix-en-Provence, 6-8 octobre 2008. Société préhistorique française, Paris, pp 373-385

Foucher P, San Juan-Foucher C, Vercoutere C, Ferrier C, Seronie-Vivien MR, de la Peña P, Fernandes P, Servelle C, Colonge D (2016) Raw material procurement and use at Gargas Cave (Hautes-Pyrénées, France): a Pyrenean-foothill economy during the Gravettian period. Munibe (Antropologia-Arkeologia) 67:253-268. https://doi.org/10. 21630/maa.2016.67.mis10

García-Rojas M (2014) Dinámicas de talla y gestión de las materias primas silíceas a finales del Pleistoceno en el País Vasco. Dissertation, University of the Basque Country

Gómez de Soler B, Soto M, Vallverdú J, Vaquero M, Bargalló A, Chacón MG, Romagnoli F, Carbonell E (2020) Neanderthal lithic procurement and mobility patterns through a multi-level study in the Abric Romaní site (Capellades, Spain). Quat Sci Rev 237:106315. https:// doi.org/10.1016/j.quascirev.2020.106315

Gómez-Olivencia A, Arceredillo D, Álvarez-Lao DJ, Garate D, San Pedro Z, Castaños P, Rios-Garaizar J (2014) New evidence for the 
presence of reindeer (Rangifer tarandus) on the Iberian Peninsula in the Pleistocene: an archaeopalaeontological and chronological reassessment. Boreas 43(2):286-308. https://doi.org/10.1111/bor.12037

González-Morales MR, Straus LG (2013) La ocupación gravetiense de la cueva de El Mirón (Ramales de la Victoria, Cantabria) y el contexto del arte paleolítico temprano de la cuenca del Asón. In: de las Heras C, Lasheras JA, Arrizabalaga A, de la Rasilla M (eds) Pensando el Gravetiense: nuevos datos para la Región Cantábrica en su contexto peninsular y pirenaico. Museo Nacional y Centro de Investigación de Altamira, Madrid, pp 289-300

Goutas N, Simonet A (2009) Le secteur GG2 de la grotte du Pape à Brassempouy (Landes): un dépôt intentionnel d'armes gravettiennes? Bull Société Préhistorique Française 106(2):257-291

Guillermin P (2008) Les "Périgordiens" en Quercy: l'exemple du gisement des Fieux. PALEO 20:125-140

Hoffmann DL, Utrilla P, Bea M, Pike AWG, García-Díez M, Zilhao J, Domingo R (2017) U-series dating of Palaeolithic rock art at Fuente del Trucho (Aragón, Spain). Quat Int 432:50-58. https://doi.org/10. 1016/j.quaint.2015.11.111

Homans GC (1958) Social Behavior as Exchange. Am J Sociol 63(6): 597-606. https://doi.org/10.1086/222355

Iriarte-Chiapusso MJ, Arrizabalaga A (2015) El yacimiento arqueológico de Bolinkoba (Abadiño, Bizkaia). Crónica de las investigaciones en la cavidad. Secuencia estratigráfica y cronología numérica. In: Iriarte-Chiapusso MJ, Arrizabalaga A (eds) Bolinkoba (Abadiño) y su yacimiento arqueológico: arqueología de la arqueología para la puesta en valor de su depósito, a la luz de las excavaciones antiguas y recientes. Diputación Foral de Bizkaia, Bilbao, pp 5-88

Lacarrière J, Goutas N, Normand C, Simonet A (2011) Vers une redéfinition des occupations gravettiennes de la grotte d'Isturitz (Pyrénés-Atlantiques, France): révision critique des collections "anciennes" par l'approche intégrée des données lithiques, fauniques et de l'industrie osseuse. In: Goutas N, Klaric L, Pesesse $\mathrm{D}$, Guillermin $\mathrm{P}$ (eds) À la recherche des identités gravettiennes : actualités, questionnements et perspectives. Société Préhistorique Française, Paris, pp 67-83

Laplace G (1972) La typologie analytique et structurale: base rationnelle d'étude des industries lithiques et osseuses. Banq Données Archéologiques 932(1972):91-143

Marín-Arroyo AB, Ríos-Garaizar J, Straus LG, Jones JR, de la Rasilla M, González Morales MR, Richards M, Altuna J, Mariezkurrena K, Ocio D (2018) Chronological reassessment of the Middle to Upper Paleolithic transition and Early Upper Paleolithic cultures in Cantabrian Spain. PLoS One 13(4):1-20. https://doi.org/10.1371/ journal.pone.0194708

Martínez L (2015) El Gravetiense en el sector occidental cantábrico y sus conexiones pirenaicas. Dissertation, University of Oviedo

Morala A (2017) Les silicifications des bassins versants de la Dordogne et de la Vézère: évaluation des ressources lithologiques et implications archéologiques. Musée National de Préhistoire, Les Eyzies-deTayac-Sireuil

Normand C (1986) Inventaire des gîtes à silex de la Chalosse. Bull Société Borda 402:121-140

Normand C (1993) Un atelier de taille de pièces à dos à Tercis, Landes. Archéologie des Pyrénées Occident des Landes 12:25-51

Normand C (2002) Les ressources en matières premières siliceuses dans le basse vallé de l'Adour et de ses affluents. In: Cazals N (ed) Comportements techniques et économiques des societies du Paléolithique Supérieur dans le context pyrenéen, Project Collectif de Recherche 2002. Service Regional de l'Archéologie de MidiPyrénées, Toulouse, pp 26-46

Normand C, Goutas N, Lacarrière J, Simonet A (2012) El Gravetiense de la cueva de Isturitz: nuevas investigaciones, nuevos datos. In: de las Heras C, Lasheras JA, Arrizabalaga A, de la Rasilla M (eds) Pensando el Gravetiense: nuevos datos para la Región Cantábrica en su contexto peninsular y pirenaico. Museo Nacional y Centro de Investigación de Altamira, Madrid, pp 161-183

Prieto A (2018) Procurement and management of quartzite in the Cantabrian Region: the Middle and Upper Palaeolithic in the Deva, Cares and Güeña valleys. University of the Basque Country, Dissertation

Prieto A, García-Rojas M, Sánchez A, Calvo A, Domínguez-Ballesteros E, Ordoño J, García-Collado MI (2016) Stones in motion: cost units to understand flint procurement strategies during the Upper Palaeolithic in the south-western Pyrenees using GIS. J Lithic Stud 3(1):1-28. https://doi.org/10.2218/jls.v3i1.1310

Prieto A, Yusta I, Arrizabalaga A (2020) From petrographic analysis to stereomicroscopic characterisation: a geoarchaeological approach to identify quartzite artefacts in the Cantabrian Region. Archaeol Anthropol Sci 12:32. https://doi.org/10.1007/s12520-019-00981-7

Rémicourt M, Tallet P, Fernandes P, Rué M, Briand T, Simonet A, Pasquini A, Fedoroff N, Picavet R, Bernard C (2010) Les occupations gravettiennes de Hin de Diou, à Pujo-Le-Plan. Paléotime-SRA Aquitaine, Villard-de-Lans

Rios-Garaizar J (2012) Industria lítica y sociedad del Paleolítico medio al superior en torno al Golfo de Bizkaia. PUbliCan, Santander

Roselló E, Morales A (2011) Estudio de los peces del yacimiento de Aitzbitarte III (Zona de entrada). In: Altuna J, Mariezkurrena K, Rios-Garaizar J (eds) Ocupaciones humanas en Aitzbitarte III (País Vasco). 33.600-18.400 BP (Zona de entrada a la cueva). Gobierno Vasco, Vitoria-Gasteiz, pp 507-516

Sáenz de Buruaga A, García-Rojas M, Retolaza I (2005) Aproximación a la interpretación tecno-tipológica del conjunto industrial de tradición gravetiense de Prado (Burgeta, Araba). Estud Arqueol Alavesa 22: $51-68$

San Emeterio A, Ríos-Garaizar J (2017) Estudio de las industrias líticas de la cueva de Aitzbitarte III (zona del interior). In: Altuna J, Mariezkurrena K, Ríos J, San Emeterio A (eds) Ocupaciones Humanas en Aitzbitarte III (País Vasco). 26.000-13.000 BP (Zona Profunda de la cueva). Gobierno Vasco, Vitoria-Gasteiz, pp 31-186

San Juan-Foucher C (2013) Industria ósea decorada y arte mueble del Gravetiense pirenaico: perspectivas territoriales actualizadas. In: de las Heras C, Lasheras JA, Arrizabalaga A, de la Rasilla M (eds) Pensando el Gravetiense: nuevos datos para la Región Cantábrica en su contexto peninsular y pirenaico. Museo Nacional y Centro de Investigación de Altamira, Madrid, pp 461-483

San Juan-Foucher C, Vercoutère C (2003) Les «sagaies d'Isturitz» des niveaux gravettiens de Gargas (Hautes-Pyrénées) et de Pataud (Dordogne). Préhistoires Méditerranéennes 12:75-94

Sánchez de la Torre M, Angyal A, Kertész Z, Dubernet S, Le Bourdonnec FX, Papp E, Szoboszlai Z, Török Z, Csepregi A, Szikszai Z (2019) Micro-PIXE studies on prehistoric chert tools: elemental mapping to determine Palaeolithic lithic procurement. Archaeol Anthropol Sci 11(6):2375-2383. https://doi.org/10.1007/s12520-018-0668-9

Sánchez A, Domínguez-Ballesteros E, García-Rojas M, Prieto A, Calvo A, Ordoño J (2016) Patrones de aprovisionamiento de sílex de las comunidades superopaleolíticas del Pirineo occidental: el "coste" como medida de análisis a partir de los SIG. Munibe (Antropologia-Arkeologia) 67:235-252. https://doi.org/10.21630/ maa.2016.67.mis02

Sauer F (2016) Raw material procurement economy and mobility in Late Palaeolithic Northern Bavaria. Quartär 63:125-135. https://doi.org/ 10.7485/QU63_6

Séronie-Vivien MR (1994) Pétrographie des silex préhistoriques du gisement paléolithique de l'abri Dufaure (Sorde l'Abbaye, Landes). Bull Société linnéenne Bordeaux 22(1):23-29

Séronie-Vivien M, Séronie-Vivien MR, Foucher P (2006) L'économie du silex au Paléolithique supérieur dans le bassin d'Aquitaine. Le cas des silex à lépidorbitoïdes des Pyrénées centrales. Caractérisation et implications méthodologiques. PALEO 18:193-216 
Simonet A (2010) Typologie des armatures lithiques gravettiennes de la grotte d'Isturitz (Pyrénées-Atlantiques, France). Archaeopress, Oxford

Simonet A (2012a) Brassempouy (Landes, France) ou la matrice gravettienne de l'Europe. Université de Liège, Liège

Simonet A (2012b) Des apprentis gravettiens ont-ils confectionné des armatures lithiques à Tercis (Landes, France)? PALEO 23:249-276

Simonet A (2012c) Le secteur GG2 au fond de la grotte du Pape: un dépôt intentionnel d'armes gravettiennes sacrifiées? In: Simonet A (ed) Brassempouy (Landes, France) ou la matrice gravettienne de l'Europe. Université de Liège, Liège, pp 51-82

Simonet A (2017) Gravettians at Brassempouy (Landes, France), 30,000 BP: a semi-sedentary territorial organization? World Archaeol 49(5):648-665. https://doi.org/10.1080/00438243.2017.1359109

Tarriño A (2000) Estudio de la procedencia de los sílex recuperados en el yacimiento de Labeko Koba (Arrasate, País Vasco). In: Arrizabalaga A, Altuna J (eds) Labeko Koba (País Vasco). Hienas y humanos en los albores del Paleolítico superior, Sociedad de Ciencias Aranzadi, San Sebastián, pp 345-354

Tarriño A (2006) El sílex en la Cuenca Vasco-Cantábrica y Pirineo navarro: caracterización y su aprovechamiento en la Prehistoria. Museo Nacional y Centro de Investigación de Altamira, Madrid

Tarriño A (2011) Procedencia de los sílex de la cueva de Aitzbitarte III (Rentería, Gipuzkoa). In: Altuna J, Mariezkurrena K, Rios J (eds) Ocupaciones humanas en Aitzbitarte III (País Vasco). 33.60018.400 BP (Zona de entrada a la cueva). Gobierno Vasco, VitoriaGasteiz, pp 353-374

Tarriño A (2013) Los sílex de Mugarduia Sur (Urbasa, Navarra). In: Barandiarán I, Cava A, Aguirre M (eds) El taller de sílex de Mugarduia Sur: una ocupación de Urbasa (Navarra) durante el Gravetiense. University of the Basque Country, Vitoria-Gasteiz, pp 525-547

Tarriño A, Aguirre M (1997) Datos preliminares sobre fuentes de aprovisionamiento de rocas silíceas en algunos yacimientos paleolíticos y postpaleolíticos del sector oriental de la Cuenca Vasco-Cantábrica. Veleia 14:101-116
Tarriño A, Elorrieta I (2012) La explotación de los recursos abióticos durante el Gravetiense cantábrico. Primeros datos sobre el Pirineo occidental y la Cuenca Vasco-Cantábrica. In: de las Heras C, Lasheras JA, Arrizabalaga A, de la Rasilla M (eds) Pensando el Gravetiense: nuevos datos para la Región Cantábrica en su contexto peninsular y pirenaico. Museo Nacional y Centro de Investigación de Altamira, Madrid, pp 330-346

Tarriño A, Arriortua MI, Elorza J (1989) Estudio geológico del área de Peñacerrada (Álava): petrografía y cristalografía de las silicificaciones existentes. Cuad Sección Eusko-Ikaskuntza (Ciencias Nat) 5:45-135

Tarriño A, Yusta I, Aguirre M (1998) Indicios de circulación a larga distancia de sílex en el Pleistoceno Superior. Datos petrográficos y geoquímicos de materiales arqueológicos de Antoliñako Koba. Bol Soc Esp Mineral 21(A):200-201

Tarriño A, Olivares M, Etxebarria N, Baceta JI, Larrasoaña JC, Yusta I, Pizarro JL, Cava A, Barandiarán I, Murelaga X (2007) El sílex de tipo "Urbasa". Caracterización petrológica y geoquímica de un marcador litológico en yacimientos arqueológicos del Suroeste europeo durante el Pleistoceno superior y Holoceno inicial. Geogaceta 43:127-130

Tarriño A, Elorrieta I, García-Rojas M (2015) Flint as raw material in prehistoric times: Cantabrian Mountain and Western Pyrenees data. Quat Int 364:94-108. https://doi.org/10.1016/j.quaint.2014.10.061

Turq A, Faivre JP, Gravina B, Bourguignon L (2017) Building models of Neanderthal territories from raw material transports in the Aquitaine Basin (southwestern France). Quat Int 433:88-101. https://doi.org/ 10.1016/j.quaint.2016.02.062

Yravedra J (2007) Nuevas contribuciones en el comportamiento cinegético de la Cueva de Amalda. Munibe (AntropologiaArkeologia) 58:43-88

Publisher's note Springer Nature remains neutral with regard to jurisdictional claims in published maps and institutional affiliations. 